\title{
Index to Volume 21, 1997
}

\section{Compiled by Linda English}

PART I - SUBJECTS
PART II - CONTRIBUTORS
$17-24$

\section{PART I - SUBJECT INDEX. (C) = Correspondence}

Abbasiah Hospital. Egypt. A visit. Rafeek Mahmood et al (Briefing) 45-46

Abramovic, Marina. Razor head. Performance art. Sean Spence (Psychiatry and the media) 53-55

Accident and emergency departments

Holding powers. K. R. Nicholls 615-617

Psychiatric presentations to a department. David Ellis and Simon Lewis 627-630

Urgent psychiatric assessment in an inner-city department. M. J. Crawford and D. Kohen 625-626

Adolescence

Emergency admissions to a regional unit. Andrew Cotgrove $604-608$

Substance misuse in secondary students in Hong Kong. Waisong Yeung 561-562

Survey of young offenders in a regional secure unit. C. Lengua et al 535-537

see also Childhood and adolescence

Afriliate status. Meetings with doctors in the staff grades. George Stein 405-407

Africa

Child abuse and neglect in sub-Saharan Africa. O. O. Famuyiwa 336-338

Rebuilding psychiatry in Uganda. Jed Boardman and Emilio Ovuga (Briefing) 649-655

Visit to Abbasiah Hospital, Egypt. Rafeek Mahmood et al (Briefing) 45-46

Alcohol misuse

Attendance rate at an alcohol problem clinic. Imad M. Ali and Andrew J. McBride 343-345

Chlormethiazole or chlordiazepoxide? Mark Salter (C) 186. Hugh Williams (C) 187

Detoxification: postal survey. Meena Agarwal et al 205-208

Diazepam and detoxification. Zelda Summers et al (C) 244-245

Disulfiram implantation. J. C. Hughes and C. C. H. Cook (C) 186. M. T. Malcolm (C) 375-376

Injecting some audit into substance misuse services. Beelin Baxter et al (Audit) 360-363

Psychiatric liaison services to the Scottish Liver Transplant Unit. Sean Lynch and Sukh Lally (C) 517

Survey of attitudes among future doctors. John J. Sharkey and Diana Patterson 16-18

American Board of Psychiatry and Neurology (ABPN). Joint meeting with the Royal College of Psychiatrists, 6 July 1996. Anne Dean (Head of Postgraduate Educational Services) (Royal College) 306

Anorexia nervosa. Talking about Anorexia. Maroushka Munro (Janet Treasure) (Book review) 671

Antipsychotics

Council Report. The association between antipsychotic drugs and sudden death. Working Party on the Association Between Antipsychotic Drugs and Sudden Death (Royal College) 730-732

High dose prescribing. Andrew Clark (C) 58-59
Monitoring of patients on high dose medication. Kate Sillifant et al 612-614

Out-patients on 'higher dose' drugs. John R. Taylor and Ian B. Cookson (Audit) 445-448

Prescribing in light of the consensus statement of the College. K. L. Newton et al 408-410

Rapid tranquillisation: are we getting it right? Laura Mannion et al $411-413$

Use of high dose medication. Graeme Yorston and Alison Pinney (Audit) 566-569

see also Chlorpromazine equivalents, Clozapine, Neuroleptics, Risperidone and Tardive dyskinesia

Appeals

Genetic linkage studies in schizophrenia 255

Request for information. D. M. Hambridge (C) 245

Appointments. President of International Narcotics Control Board: Hamid Ghodse 527

Art

Paintings in Hospitals open new gallery 527

Razor head. Performance art of Marina Abramovic. Sean Spence (Psychiatry and the media) 53-55

see also Psychiatry in art

Attention deficit disorder. Drug treatment: survey of professional consensus. Kapil Sayal and Eric Taylor 398-400 Audit

Administration of ECT by trainee psychiatrists. An audit of supervision, adequacy of tuition and attitudes. Jonathan Hillam et al 217-220

Drug management of acute behavioural disturbance. Siri-Ann Robling et al 440-444

First light: old age psychiatry in Wolverhampton 1995 to 1996. David Jolley et al 503-505

Injecting some audit into substance misuse services. Beelin Baxter et al 360-363

Lithium monitoring in hospital and general practice. Ann Ryman 570-572

Out-patients on 'higher dose' antipsychotics. John R. Taylor and Ian B. Cookson 445-448

Psychosurgery: description and outcome study of a regional service. R. P. Snaith et al 105-109

Psychotropic medication in learning disabilities: audit as an alternative to legislation. H. E. J. Miller et al 286-289

Repeat audit of the Cognitive Analytic Therapy Clinic at Guy's Hospital. Mark Dunn et al 165-168

Reports prepared for Mental Health Review Tribunals and Managers' Reviews. Phil Davison and Alberto Perez de Albeniz 364-366

Use of high dose antipsychotic medication. Graeme Yorston and Alison Pinney 566-569

Who's assessing needs-led assessment? Peter H. Dick et al 290-293

Australia. Being there (in praise of general practice). Alcuin Wilkie (Briefing) 48-49

Awards

Communication 127

Hans-Jörg Weitbrecht Scientific 591

Kurt Schneider Scientific $\mathbf{3 1 8}$ 
Mental Health Award available to clinicians involved in schizophrenia 736

Plain English Campaign Award for Royal College 127 see also Royal College: Prizes and awards

Beckett, Samuel. Portraits of the artist in exile. Roisin Kemp and Josephine Loftus (Psychiatry and the media) 656-658

Behavioural disturbance. Acute. Drug management. Siri-Ann Robling et al (Audit) 440-444

Benzodiazepines. Risks, benefits or dependence. A reevaluation. Council Report (Royal College) 798

Bexley Hospital. The population nine years on. S. J. Kelly 542-544

Bipolar affective disorder. Doses of carbamazepine and valproate. David Taylor and Denise Duncan (Drug information quarterly) 221-223. J. B. Grace and A. H. Young (C) 784 David Taylor and Denise Duncan (Authors' reply) (C) 784

Birmingham. Community mental health team for the homeless. Martin Commander et al 74-76

Blake Marsh, Dr. Blake Marsh Lectures. Kenneth Day and Joze Jancar 26-29

Book reviews

Child and Adolescent Services. Young People and Protective Legislation. Safeguards for Young Minds. R. Williams and R. White (eds) (Philip Graham) 669-670

Depression in General Practice. André Tylee et al (Patricia R. Casey) 668-669

Living in the Community. Diana Rose (Tom Burns) 670

Needs Assessment in General Practice. S. J. Gillam and S. A Murray (eds) (Tony Kendrick) 671

Options for Improving Patient Care in Schizophrenia. Hugh Freeman (ed.) (D. A. W. Johnson) 669

Talking about Anorexia. Maroushka Munro (Janet Treasure) 67I

You're on Trial. Sheila Hollins et al (Shaun Gravestock) 668

You're under Arrest. Sheila Hollins et al (Shaun Gravestock) 668

Botulinum toxin. Tardive dyskinesia - how is it prevented and treated? P. Duffey et al (C) 724

Boyd, Bill. In conversation. David Tait (Interview) 769-774

Brazil

Dioclein - new drug from an old plant. Letter. John Dunn (Briefing) 235-236

The rocky road - crack in Brazil. Letter. John Dunn 373-374 Briefings

Bibliographic databases in psychiatry: an overview. Alexander J. Mitchell et al 578-580

Conference reports

Eleventh Annual TAPS Conference. Hugh Freeman 233--234

Fourth European Trainees' Forum. Peter Cornwall and Laurence Sheldon (CTC) 117

Future directions of psychotherapy in the NHS: adaptation or extinction? Kate Lockwood 180

Inaugural meeting of the Special Interest Group for Women in Psychiatry. Anne Cremona (Chairman, Special Interest Group for Women in Psychiatry) 179

International conference on philosophy and mental health. Christopher Howard (Chairman, Special Interest Group in Philosophy) 179-180

1996 Trainees' Forum. Peter Cornwall (CTC) 47

The conversion of Holloway Sanatorium. Jane Knowles 232

Foreign reports

Australia - being there (in praise of general practice). Alcuin Wilkie 48-49

Cocaine and social transformation in Trinidad and Tobago. Letter from Trinidad. Hari Maharajh 184-185

Dioclein - a new drug from an old plant. Letter from Brazil. John Dunn 235-236

Is there a real need for a short-stay unit in Al Ain, United Arab Emirates? Tewfik K. Daradkeh et al 237-239

Long-term psychiatric care in Papua New Guinea. Fiona S. Noble 113-116
Mental illness in Goa, India. Vikram Patel 299-301

Psychiatry in Lithuania: the highest rate of suicide in the world. Rahman Haghighat 716-719

Psychosocial support in the shadow of war. Nancy Cohn and Jack Piachaud 714-715

Rebuilding psychiatry in Uganda. Jed Boardman and Emilio Ovuga 649-655

Visit to Abbasiah Hospital, Egypt. Rafeek Mahmood et al 45-46 Meeting Gerald Caplan. Gordon Langley 181-183

A patient's story. Tricia Adams 438-439

Psychological care of staff following traumatic incidents at work. Ronan J. Mclvor et al 176-178

Britain

Health research on the Irish. Gerard Leavey et al (Editorial) 739-740 see also Birmingham, London, Newcastle Clozapine Clinic, Nottingham, Oxford University Department of Psychiatry, Reading model, Scotland and Wolverhampton

Capital punishment. Psychiatry and the death penalty. Rob Ferris 746-748. Invited commentary. Peter Hodgkinson 749-750

Caplan, Gerald. Meeting him. Gordon Langley (Briefing) 181-183

Carbamazepine. Valproate. Doses in bipolar affective disorder. David Taylor and Denise Duncan (Drug information quarterly) 221-223. J. B. Grace and A. H. Young (C) 784 David Taylor and Denise Duncan (Authors ' reply) (C) 784

Care homes. Neglected health needs of people with dementia 591

Care Programme Approach (CPA)

Clinical risk management: an emerging agenda for psychiatry. David Roy (Risk assessment) 162-164

Faith or fact. Andrew Al-Adwani and D. W. Nabi (C) 725

GPs. Andrew Al-Adwani and Waheed Nabi (C) 303

Responsible medical officers and keyworkers: conflict of roles. Ikechukwu Obialo Azuonye (C) 661-662

Should it carry a government health warning? P. E. Watson 432-434. Jason Wheeler (C) 723. P. E. Watson (C) 723

Should psychiatrists support CPA, guidelines and routine outcome measurement? Paul Lelliott (Director, Research Unit) (Editorial) 1-2. John M. Eagles (C) 377

Time for frank talking. Tom Burns and Judy Leibowitz 426-429. Comment. David Kingdon 430-431

\section{Carers}

Cherie Booth launches CarersLine 59|

Impact on women who care for those with schizophrenia. Marcia Scazufca and Elizabeth Kuipers (Women's mental health) 469-471

Role in the information process in dementia. Rahul Rao 264-266

Twenty-four hour psychiatric services. Jacqueline $M$. Atkinson (C) 123

Childhood

Abuse

Abuse and neglect in sub-Saharan Africa. O. O. Famuyiwa 336-338

False memories of child sexual abuse. Mike Hobbs (Video review) 119

Group therapy in the treatment of childhood sexual abuse. Janet Boakes 754-756

Negative views of the mother after sexual abuse. Janet $D$. Feigenbaum (Women's mental health) 477-479

NEWPIN: an opportunity for positive change. Myra Gurr and Anne Hansen (Women's mental health) 480-482

Reported recovered memories of child sexual abuse. Working Group on Reported Recovered Memories of Child Sexual Abuse (Royal College) 663-665

Workload and sexual abuse: an argument for joint commissioning. Mary Cole and Margaret Vereker 414-417

Concerns about the children of psychiatric in-patients what the parents say. Fiona Stormont et al 495-497

Drug treatment in attention deficit disorder. Kapil Sayal and Eric Taylor 398-400 
Meeting the psychiatric needs of children in foster care. Social workers' views. Jeannette Phillips 609-611

Nursery observation in the training of child psychiatry registrars. Alicia Etchegoyen and Joanne Stubley 156-159

Psychiatric emergencies: assessing parents of dependent children. Barbara Hatfield et al 19-22

Psychological support for a community paediatric nursing team. Gill Salmon and Anne Marie Connor 350-352

Psychosocial support in the shadow of war. Nancy Cohn and Jack Piachaud (Briefing) 714-715

Women and children living with HIV infection. Diane Melvin and Lorraine Sherr (Women's mental health) $472-476$

\section{Childhood and adolescence}

Child and Adolescent Services. Young People and Protective Legislation. Safeguards for Young Minds. R. Williams and R. White (eds) (Philip Graham) (Book review) 669-670

Donald John Brooksbank. Note. Vanessa Cameron 383

Non-attendance at clinics. Simon Smith et al (C) 303

Paediatrics in child and adolescent psychiatric training. Oonagh Bradley (Education) 294-296

Predicting attendance at clinics. K. Weir (C) 243

Role conflict and barriers to learning for senior registrars. D. M. Eminson and J. M. Green 339-342

Self-poisoning: service-related characteristics. Ashraf Nasr et al 267-269

Violent children and the media. Susan Bailey (Psychiatry and the media) 371-372

see also Adolescence

Chlordiazepoxide. Or chlormethiazole? Mark Salter (C) 186. Hugh Williams (C) 187

Chlormethiazole. Or chlordiazepoxide? Mark Salter (C) 186. Hugh Williams (C) 187

Chlorpromazine equivalents. Consensus of opinion for both clinical and research applications. Maria Atkins et al (Drug information quarterly) 224-226

Christmas competitions

Crossword. Oedipus and Witzelsucht 783

Winners 240

Client held records. Introduced by a community mental health team. Evaluation. Anna Stafford and Richard Laughame 757-759

\section{Clinical effectiveness}

The College. Robert Kendell (President) (Editorial) 385-386 A series of perspectives. Sarah Marriott (Research Unit) 389

Using evidence about it in everyday psychiatric practice. John Geddes 390-393

Clinical practice guidelines. Should psychiatrists suppor CPA, guidelines and routine outcome measurement? Paul Lelliott (Director, Research Unit) (Editorial) 1-2

\section{Clozapine}

Newcastle Clinic. Sandra L. Tough et al 492-494

Tardive dyskinesia - how is it prevented and treated? James G. Longhurst and Erica L. Weiss (C) 723-724

Cocaine. Social transformation in Trinidad and Tobago. Hari Maharajh (Briefing) 184-185

Cognitive analytic therapy. Repeat audit of the Clinic at Guy's Hospital. Mark Dunn et al (Audit) 165-168

Cognitive-behavioural therapy. Training for junior psychiatric trainees. Andrew Brittlebank and Julie Owens (Education) $169-170$

Collegiate Trainees' Committee (CTC)

Gary Sullivan (Trainees' forum) 358-359

Position on the use of logbooks in training. Gary Sullivan (Former Chairman, CTC) et al (Trainees' forum) 278-279

Community Care Orders

Leave of Absence. Consultants' views in Scotland. Jacqueline M. Atkinson et al 91-94

Unexpected therapeutic benefit of an application. Allan I. F. Scott (C) 124
Community interviewing. Increasing staff safety. Richard A. Powell and Brian Kidd (C) 187

Community mental health centres. Psychiatric beds attached to a centre. Jed Boardman et al 202-204

Community mental health teams

Evaluation of a client held record introduced by a team. Anna Stafford and Richard Laugharne 757-759

For the homeless in Birmingham. Martin Commander et al 74-76

Members of a team. Benjamin Lucas 547-549

Psychiatric admission for homelesss people: impact of a specialist team. Martin Commander et al 260-263

Team for the elderly: survey of GPs' views on the service. Rebecca Eastley and Mike Nowers 88-90

Community paediatric nursing teams. Psychological support. Gill Salmon and Anne Marie Connor 350-352

Community psychiatric nurses

Occupational therapists. Survey of roles. Pam Filson and Tony Kendrick 70-73

Professional attitudes in the UK towards neuroleptic maintenance therapy in schizophrenia. D. A. W. Johnson and J. G. C. Rasmussen 394-397

Community psychiatry. In the RAF. Julian C. Hughes 418-421. G. E. Reid (C) 786-787

Community support bed units. First twelve months. Martin Knapp (C) 57-58

Computers see Computers in psychiatry, Databases and Internet

Computers in psychiatry. Psychiatry and the WWW: some implications. C. Senior et al 775-778

\section{Conferences}

Women, mental health and the family. Henrikje Klasen et al (Editorial) 467-468

see also Briefings: Conference reports

\section{Confidentiality}

College Working Party 255

Tarasoff and the duty to warn third parties. Mark Turner and Michael Kennedy (Editorial) 465-466. Aileen Blower and Mark Cohen (C) 724-725

Consent

Long-term medication in depot clinics and patients' rights. Nigel Eastwood and Robert Pugh 273-275

Psychiatric advance directives: reconciling autonomy and non-consensual treatment. Adina Halpern and George Szmukler (Editorial) 323-327

Tardive dyskinesia: risk disclosure and informed consent in the Netherlands. Walter Pierre Bouman and Jon ArcelusAlonso (C) 302

To treatment. Trust matters as much as information. Teifion Davies 200-201

Constant observation. Of psychiatric in-patients. Study of effects. Olakunle Ashaye et al 145-147

Consultants

Criteria for appointment to an NHS post in psychiatry in the UK (Royal College) 520-521

Educational supervision sessions with trainees. I. O. Azuonye 154-155. Peter M. Herriot and Kamaldeep Bhui (C) 785-786

Essential information for filling posts. Fiona Mactier and Deenesh Khoosal 4-5

Notes of guidance for College representatives on NHS advisory consultant and honorary consultant appointments committees in the UK (Royal College) 519-520

Recruitment. David Storer (Chairman, Manpower Committee) (Editorial) 3

Things have to get better. David Storer (Editorial) 737-738

Views of Leave of Absence and Community Care Orders in Scotland. Jacqueline M. Atkinson et al 91-94

Who retired prematurely in 1995 and 1996 . R. E. Kendell (President) and Alison Pearce (Research Unit) 741-745

Consultation-liaison. From dream to reality. Frits J. Huyse and Graeme C. Smith (Editorial) 529-531 
Continuing professional development. The Fellowship. Adam Moliver (C) 242

Corrigenda 726

\section{Costs}

First twelve months of a community support bed unit Martin Knapp (C) 57-58

Hybrid justice: proposals for the mentally disordered in the Crime (Sentences) Bill. Nigel Eastman (Editorial) 129-131

Physical health care for self-injuring patients. Mark Swinton and Sarah Smith 538-54

Specialist work schemes: user satisfaction and costs. Justine Schneider and Angela Hallam 331-333

see also Health economics

Counselling

Psychotherapy and trainees. Current practice, perceived importance and the question of lay counsellors. Peter Byrne and David Meagher (Trainees' forum) 707-710

Support services for civil emergencies and major incidents. Anne Nightingale et al 486-488

Crack. The rocky road - crack in Brazil. Letter. John Dunn 373-374

Creativity. Psychotic patients and patent applications. David V. James and Paul L. Gilluley 764-768

Crime. Official statistics - no reassurance for the victims Tom McClintock (Editorial) 258-259

Crime (Sentences) Bill. Hybrid justice: proposals for the mentally disordered. Ethical, legal and health service cost implications. Nigel Eastman (Editorial) 129-131

Criminal Procedure Act (Scotland) 1995. New legislation for mentally disordered offenders. Derek Chiswick (Medicolegal) 110-112

Cultural psychiatry. Teaching cultural aspects of psychiatry. Margreet Peutz 160-161

Daily Living Programmes. First twelve months of a community support bed unit. Martin Knapp (C) 57-58

Databases. Bibliographic databases in psychiatry: an overview. Alexander J. Mitchell et al (Briefing) 578-580

Day hospitals. Predictors of length of stay in patients Sukhwinder S. Shergill et al 760-763

Death penalty. Psychiatry. Rob Ferris 746-748. Invited commentary. Peter Hodgkinson 749-750

Deaths reported

Aron, Karl Wolfgang 667

Brown, James Henderson 667

Cox, Murray Newell 667

Craft, Ann 734

Davenport, Margaret 667

Emery, Ralph 667

Esher, Frederick Justus Swinton 667

Finalyson, Paul Farrington 667

Fischer, Emanuel 734

Hamilton, Marian Watling 667

Holland, Lee Kerr 667

Kehoe, Michael James 667

Kushlick, Albert 734

Lavin, Noel Ignatius 734

Lucy, John Douglas 734

McCance, Colin 735

McConnell, Joan 735

McDonnell, Dermot Joseph 735

Mcllvenna, Mervyn 735

McIntyre, William Morison 735

McWhinnie, James Barr 735

Pasmore, Jean 735

Richardson, Barbara 735

Roberts, Constance Dix 735

Robertson, James Finlay 735
Romano, John 735

Scott, William Clifford Munro 735

Seaton, Shirley 735

Siddiqui, Abdur Razzaque 735

Smedberg, Daphne 735

Stage, Charlotte 735

Sutherland, Sinclair Stewart 735

Van De Merwe, Theunis Jeremia 735

Vincenzi, Julius Edward 735

Wood, Eric Alexander Masterton 735

Xavier, Charles Baptisa 667

Defeat Depression Campaign. Mid-point evaluation of its impact on GPs. Ann Macaskill et al 148-150

Deliberate self-harm

Characteristics of patients admitted to in-patient psychiatric care following parasuicide. Polash Shajahan et al 695-698

Child and adolescent self-poisoning: service-related characteristics. Ashraf Nasr et al 267-269

Costs of physical health care for patients. Mark Swinton and Sarah Smith 538-541

Effects of education on attitudes. Gill Turnbull and Trudie Chalder 334-335

Psychiatric liaison services to the Scottish Liver Transplant Unit. Sean Lynch and Sukh Lally (C) 517

Razor head. Performance art of Marina Abramovic. Sean Spence (Psychiatry and the media) 53-55

Delusions. Description of primary delusions: confusion in standard texts and among clinicians. R. H. McAllisterWilliams 346-349. Imad M. Ali (C) 660-661

Dementia

Forgetfulness and blame. Tony Whitehead (C) 725-726

Humble pie. Henry R. Rollin (Vignette) 316-317

Interim statement on anti-dementia drugs. Working Group of Section for Psychiatry of Old Age (Royal College) 586-587

Neglected health needs of people in care homes 591

Role of carers in the information process. Rahul Rao 264-266

Depot clinics. Long-term medication and patients' rights. Nigel Eastwood and Robert Pugh 273-275

Depression

Defeat Depression Campaign. Mid-point evaluation of its impact on GPs. Ann Macaskill et al 148-150

Depression in General Practice. André Tylee et al (Patricia R. Casey) (Book review) 668-669

Knowledge of the Edinburgh Postnatal Depression Scale among psychiatrists and GPs. Peter Aitken and Robin Jacobson 550-552

Review of ECT prescription and outcome. Carol Robertson and John M. Eagles 498-500

The smile in endogenous depression. Seymour Spencer (Vignette) 659

Suicide in the severely mentally ill. Sue Jackson et al (C) 59

Detoxification

Alcohol. Postal survey. Meena Agarwal et al 205-208

Diazepam. Zelda Summers et al (C) 244-245

Diagnoses. Role of carers in the information process in dementia. Rahul Rao 264-266

Diazepam. Detoxification. Zelda Summers et al (C) 244-245

Dioclein. New drug from an old plant. Letter from Brazil. John Dunn (Briefing) 235-236

Disasters. Counselling and support services for civil emergencies and major incidents. Anne Nightingale et al 486-488

Disulfiram. Implantation. J. C. Hughes and C. C. H. Cook

(C) 186. M. T. Malcolm (C) 375-376

Drug information quarterly

Chlorpromazine equivalents: consensus of opinion for both clinical and research applications. Maria Atkins et al 224-226

Choice of neuroleptics in epilepsy. Harry McConnell et al 642-645 
Doses of carbamazepine and valproate in bipolar affective disorder. David Taylor and Denise Duncan 221-223. J. B. Grace and A. H. Young (C) 784. David Taylor and Denise Duncan (Authors' reply) (C) 784

Psychotropics and hyponatraemia. Robyn McAskill and David Taylor 33-35. Gillian Pinner et al (C) 376. Catherine Andrews (C) 376

Tardive dyskinesia - how is it prevented and treated? Denise Duncan et al 422-425

Drug misuse

Cocaine and social transformation in Trinidad and Tobago. Hari Maharajh (Briefing) 184-185

Injecting some audit into substance misuse services. Beelin Baxter et al (Audit) 360-363

In secondary students in Hong Kong. Wai-song Yeung 561-562

Professor Hamid Ghodse 527

The rocky road - crack in Brazil. Letter. John Dunn 373-374

Task force to review services. Duncan Raistrick (Editorial) 595-596

Trainspotting and the depiction of addiction. Peter Byrne (Psychiatry and the media) 173-175

Drugs

also Alcohol misuse

Analysis of psychotropic drug advertising. John Quinn et al 597-599

Interim statement on anti-dementia drugs. Working Group of Section for Psychiatry of Old Age (Royal College) 586-587

Long-term medication in depot clinics and patients' rights. Nigel Eastwood and Robert Pugh 273-275

Management of acute behavioural disturbance. Siri-Ann Robling et al (Audit) 440-444

Psychotropic medication in learning disabilities: audit as an alternative to legislation. H. E. J. Miller et al (Audit) 286-289

Rapid tranquillisation: are we getting it right? Laura Mannion et al $411-413$

Staff perception on reduction of medication in patients with chronic schizophrenia. A. Thomas et al 692-694

Treatment in attention deficit disorder. Kapil Sayal and Eric Taylor 398-400

What to write on Mental Health Act form 38. I. O. Azuonye (C) 304 see also Antipsychotics, Benzodiazepines, Botulinum toxin, Carbamazepine, Chlordiazepoxide, Chlormethiazole, Chlorpromazine equivalents, Clozapine, Cocaine, Crack, Diazepam, Dioclein, Disulfiram, Lithium, Neuroleptics, Risperidone, Selective serotonin reuptake inhibitors and Valproate

Duty to warn. Tarasoff and the duty to warn third parties. Mark Turner and Michael Kennedy (Editorial) 465-466. Aileen Blower and Mark Cohen (C) 724-725

\section{Early retirement}

Consultants who retired prematurely in 1995 and 1996 . R. E. Kendell (President) and Alison Pearce (Research Unit) 741-745

Things have to get better. David Storer (Editorial) 737-738

Economics see Costs and Health economics

ECT see Electroconvulsive therapy

Edinburgh Postnatal Depression Scale. Knowledge among

psychiatrists and GPs. Peter Aitken and Robin Jacobson 550-552

\section{Editorials}

Assessment of suicide risk. Louis Appleby (Director, National Confidential Inquiry into Suicide and Homicide by People with Mental Illness) 193-194

The College and 'clinical effectiveness'. Robert Kendell (President) 385-586

Consultation-liaison: from dream to reality. A systematic approach to developing $\mathrm{C}-\mathrm{L}$ mental health service delivery. Frits J. Huyse and Graeme C. Smith 529-531
Evidence-based medicine and the journal club: a crosssectional survey of participants' views. James P. Warner and Michael King 532-534

Flexible training in psychiatry. Ilfra Goldberg 387-388

From problems to solutions. Peter Kennedy 593-594

Health research on the Irish in Britain: invisible and excluded. Gerard Leavey et al 739-740

Hybrid justice: proposals for the mentally disordered in the Crime (Sentences) Bill. The ethical, legal and health service cost implications. Nigel Eastman 129-131

Inquiries: who needs them? Matt Muijen 132-133. Commentary. Adrian Grounds 134-135

Litigation against psychiatrists. John J. Bradley 321-322

London's mental health services. David Goldberg (London Commissioner) 65-66

Mental Health Review Tribunals: time for reform? Carole Kaplan and Paul Ralph 257

Neurosurgery for mental disorder in the UK. Chris Freeman 67-69

Nurses' help in psychiatric out-patient clinics: saving time or saving value. C. Brooker and S. Read 675-676

Official crime statistics - no reassurance for the victims of crime. Tom McClintock 258-259

Psychiatric advance directives: reconciling autonomy and non-consensual treatment. Adina Halpern and George Szmukler 323-327

Recruiting consultants. David Storer (Chairman, Manpower Committee) 3

A second exile: the mental health implications of detention of asylum seekers in the UK. Christina Pougourides 673-674

Should psychiatrists support CPA, guidelines and routine outcome measurement? Paul Lelliott (Director, Research Unit) 1-2

Tarasoff and the duty to warn third parties. Mark Turner and Michael Kennedy 465-466

Task force to review services for drug misusers. Duncan Raistrick 595-596

Things have to get better. David Storer 737-738

Twenty-four hour nursed care for people with severe and enduring mental illness. Frank Holloway 195-196

Women, mental health and the family. Henrikje Klasen et al $467-468$

Education

Core psychiatry for tomorrow's doctors. Working Party of the Education Committee (Royal College) 522-524. Roch Cantwell and John Brewin (C) 786

Effects on attitudes to deliberate self-harm. Gill Turnbull and Trudie Chalder 334-335

Evidence-based medicine and the journal club. James $P$. Warner and Michael King (Editorial) 532-534

Implementing the OSCE in Nottingham. John Brewin and Roch Cantwell 30-32

Objective structured clinical examination. O. O. Famuyiwa (C) $459-460$

Supervision sessions between consultants and trainees. I. $O$. Azuonye 154-155. Peter M. Herriot and Kamaldeep Bhu (C) 785-786

Teaching cultural aspects of psychiatry. Margreet Peutz 160-161 see also Training

Education

Cognitive-behavioural therapy training for junior psychiatric trainees. Andrew Brittlebank and Julie Owens 169-170

Membership course or masters course? Gary Sullivan and Ian R. Jones 449-450

Paediatrics in child and adolescent psychiatric training. Oonagh Bradley 294-296

Participating in the MRCPsych examinations: the patients experience. Darina Sloan et al 646-648

Psychiatric trainees' research experiences and activities in the Eastern region of Ireland. John Quinn and David Meagher 367-368 
Two management courses for senior/specialist registrars Maureen O'Brien and Gary Sullivan 229-231

Egypt. Visit to Abbasiah Hospital. Rafeek Mahmood et al (Briefing) 45-46

Elderly

A community mental health team: survey of GPs' views on the service. Rebecca Eastley and Mike Nowers 88-90

Conflicts of a 90-year-old transsexual. Yong-Lock Ong and Pam Davies (Psychiatry and the media) 720-722

Intensive home nursing. D. D. R. Williams et al 23-25

Old age psychiatry in Wolverhampton 1995 to 1996. David Jolley et al (Audit) 503-505

Service provision for people with long-term functional illness. S. Green et al 353-357

SSRI prescribing: caution required. Gillian Pinner et al (C) 376. Catherine Andrews (C) 376

Statement on continuing care for older adults with psychiatric disorder (Royal College) 588

Trainees in the specialities. Simon Thacker (C) 375. J. P. Wattis (Chairman, Section for Psychiatry of Old Age) (C) 375

Voluntecr project for people with mental health problems. Jon Spear et al 401-404

Electrocardiograms. Survey of use in psychiatry. Tom Henderson et al 136-138

Electroconvulsive therapy

Administration by trainee psychiatrists. Jonathan Hillam et al (Audit) 217-220

Effects of changes in practice over a two year period. Kate Trezise and Bill Conlon 10-12

In Scotland. Carol Robertson et al 699-702

Junior doctors' training in the theory and practice. Richard Duffett (Research Unit) and Paul Lelliott (Director Research Unit) (Trainees forum) 563-565

Review of its prescription and outcome in depression. Carol Robertson and John M. Eagles 498-500

\section{Emergencies}

Admissions to a regional adolescent unit. Andrew Cotgrove 604-608

Assessing parents of dependent children. Barbara Hatfield $e$ al 19-22

Counselling and support services for civil emergencies and major incidents. Anne Nightingale et al 486-488

Holding powers in A\&E departments. K. R. Nicholls 615-617

Improving resuscitation skills in psychiatric hospitals. Tony Winston and Gary Drybala 557-560

Non-consultant psychiatrists' knowledge of emergency detention procedures in Scotland. Martin S. Humphreys $631-635$

Rapid tranquillisation: are we getting it right? Laura Mannion et al $411-413$

Self-referrals to a large psychiatric hospital. Nicola Gray and Emad Salib 751-753

Urgent psychiatric assessment in an inner-city $A \& E$ department. M. J. Crawford and D. Kohen 625-626

Employment

Opportunities for people with mental health problems 591

Specialist work schemes: user satisfaction and costs. Justine Schneider and Angela Hallam 331-333

Enquiries see Inquiries

Epilepsy. Choice of neuroleptics. Harry McConnell et al (Drug information quarterly) 642-645

Ethics

Consent to treatment. Trust matters as much as information. Teifion Davies 200-201

Disulfiram implantation. J. C. Hughes and C. C. H. Cook (C) 186

Hybrid justice: proposals for the mentally disordered in the Crime (Sentences) Bill. Nigel Eastman (Editorial) 129-13
Loose talk: psychiatrists, the media and ethics. Philip Timms (Psychiatry and the media) 573-575

Mental disorders and genetics: ethical enquiry 318

Psychiatry and the death penalty. Rob Ferris 746-748. Invited commentary. Peter Hodgkinson 749-750

Ethnic minorities

Health research on the Irish in Britain. Gerard Leavey et al (Editorial) 739-740

Investigation of the adequacy of psychiatric interviews conducted through an interpreter. Saeed Farooq et al 209-213

Mental health services for people from black and other ethnic minorities. Dele Olajide and John Cox (Dean) (Royal College) 305

Psychiatric emergencies: assessing parents of dependent children. Barbara Hatfield et al 19-22

Europe

Fourth European Trainees' Forum. Peter Cornwall and Laurence Sheldon (CTC) (Briefing) 117

Postgraduate training in psychiatry. Walter P. Bouman (C) 120. John Sandford (C) 120

see also Irish Republic, Lithuania, Netherlands, Nordic Academy for Advanced Study and Yugoslavia

Evidence-based medicine

C. J. Haley (C) 302-303. David Marchevsky (C) 460-461

The journal club: survey of participants' views. James $P$. Warner and Michael King (Editorial) 532-534

Using evidence about clinical effectiveness in everyday psychiatric practice. John Geddes 390-393

False memory syndrome. False memories of child sexual abuse. Mike Hobbs (Video review) 119

Families

Concerns about the children of psychiatric in-patients - what the parents say. Fiona Stormont et al 495-497

Genetic linkage studies in schizophrenia 255

Negative views of the mother after childhood sexual abuse. Janet D. Feigenbaum (Women's mental health) 477-479

Psychiatric emergencies: assessing parents of dependent children. Barbara Hatfield et al 19-22

Time to amend Section 135. Peter Cutajar and Michele Hampson 640-641

Women and children living with HIV infection. Diane Melvin and Lorraine Sherr (Women's mental health) 472-476

Women, mental health and the family. Henrikje Klasen et al (Editorial) 467-468

Fellowship

CPD and the Fellowship. Adam Moliver (C) 242

Fellowships of Royal Colleges. Denis Pereira Gray (C) 120-121 Films

The psychiatrist, the patient, their relationship and the movies. Jacqueline M. Atkinson (Psychiatry and the media) 369-370

Trainspotting and the depiction of addiction. Peter Byme (Psychiatry and the media) 173-175

Forensic psychiatry

Psychiatry and the death penalty. Rob Ferris 746-748. Invited commentary. Peter Hodgkinson 749-750

Training in prison psychiatry. Eluned Dorkins (Trainees forum) 52

Visits programme for forensic senior registrars. Akintunde Akinkunmi (Trainees' forum) 280-282

see also Mentally disordered offenders

Foster care. Meeting the psychiatric needs of children. Social workers' views. Jeannette Phillips 609-611

Friday the 13th. Fatal self-harm. Emad Salib et al (C) 459

Functional illness. Service provision for elderly people with long-term illness. S. Green et al 353-357

Fundholding. Fragmentation of care. Ajit Shah and Tamal De (C) 187 
General practice

Australia - being there (in praise of general practice) Alcuin Wilkie (Briefing) 48-49

Communication between GPs and psychiatrists. Andrew Blakey et al 622-624

A community mental health team for the elderly: survey of GPs' views on the service. Rebecca Eastley and Mike Nowers 88-90

Defeat Depression Campaign. Mid-point evaluation of its impact on GPs. Ann Macaskill et al 148-150

Depression in General Practice. André Tylee et al (Patricia R. Casey) (Book review) 668-669

Fundholding and fragmentation of care. Ajit Shah and Tamal $\mathrm{De}(\mathrm{C}) 187$

GPs and the Care Programme Approach. Andrew Al-Adwani and Waheed Nabi (C) 303

HoNOS v. GP opinion in a shifted out-patient clinic. John R. Taylor and Greg Wilkinson 483-485

Knowledge of the Edinburgh Postnatal Depression Scale among psychiatrists and GPs. Peter Aitken and Robin Jacobson 550-552

Lithium monitoring in hospital and general practice. Ann Ryman (Audit) $570-572$

Needs Assessment in General Practice. S. J. Gillam and S. A. Murray (eds) (Tony Kendrick) (Book review) 671

Professional attitudes in the UK towards neuroleptic maintenance therapy in schizophrenia. D. A. W. Johnson and J. G. C. Rasmussen 394-397

Second medical recommendations and good practice. Mark McCartney (C) 58

Twenty-four hour psychiatric services. Jacqueline $M$ Atkinson (C) 123

General psychiatry. Hot beds. National survey of psychiatric intensive care units. M. Dominic Beer et al 142-144

Genetics

Linkage studies in schizophrenia 255

Mental disorders and genetics: ethical enquiry 318

Geoffrey Knight Unit. Survival. P. K. Bridges (C) 121-122

Global Assessment Scale. Predictors of length of stay in day hospital patients. Sukhwinder S. Shergill et al 760-763

Goa (India). Mental illness. Vikram Patel (Briefing) 299-301

Greek mythology. Medical and psychiatric terminology. Loukas Athanasiadis (History of psychiatry) 781-782

Grief. Helping people grieve - the role of the health worker. Mark Aveline (Video review) 118

Group and organisational dynamics. Teaching to psychiatric trainees. R. Cawthra et al (Trainees' forum) 50-51

Group therapy

In-patients: survey of staff and patients. Fiona S. Clunie 13-15 In the treatment of childhood sexual abuse. Janet Boakes 754-756

Guy's Hospital. Repeat audit of the Cognitive Analytic Therapy Clinic. Mark Dunn et al (Audit) 165-168

Health economics. In mental health. Neil Craig and Cameron Stark

1: Principles 684-686

2: Economic evaluation 687-691

Health of the Nation Outcome Scales (HoNOS)

Combination with Mental Health Descriptors. R. J. Craig (C) 585

Should psychiatrists support CPA, guidelines and routine outcome measurement? Paul Lelliott (Director, Research Unit) (Editorial) 1-2

v. GP opinion in a shifted out-patient clinic. John $R$. Taylor and Greg Wilkinson 483-485

Heart surgery. Request for information. D. M. Hambridge (C)
History of psychiatry

Greek mythology and medical and psychiatric terminology. Loukas Athanasiadis 781-782

Psychiatric services in Myanmar. A historical perspective. Khin-Maung-Zaw 506-509

HIV infection. Women and children living with it. Some psychological concerns. Diane Melvin and Lorraine Sherr (Women's mental health) 472-476

Holloway Sanatorium. The conversion. Jane Knowles (Briefing) 232

\section{Homelessness}

Community mental health teams in Birmingham. Martin Commander et al 74-76

Psychiatric admission: impact of a specialist community mental health team. Martin Commander et at 260-263

Home nursing. Intensive home nursing. An innovation in old age psychiatry. D. D. R. Williams et al 23-25

Hong Kong. Substance misuse in secondary students. Waisong Yeung 561-562

Hospitals

Improving resuscitation skills. Tony Winston and Gary Drybala $557-560$

Lithium monitoring in hospital and general practice. Ann Ryman (Audit) 570-572

Long-term psychiatric care in Papua New Guinea. Fiona S. Noble (Briefing) 113-116

A madman ahead of his time. Bedlam exhibition 736

Mental handicap resettlement readmissions. Douglas A. Spencer (C) 60

Mixed sex wards. Case report. Richard Hodgson (C) 123-124

Moving an acute psychiatric ward from a psychiatric to a general hospital setting. Neil Rothwell et al 636-639

Paintings in Hospitals open new gallery 527

Psychiatric admission for homelesss people: impact of a specialist community mental health team. Martin Commander et al 260-263

Risk factors for acute psychiatric readmission. Mandy Dixon et al 600-603

Self-referrals to a large psychiatric hospital. Nicola Gray and Emad Salib 751-753

Staff attitudes to a psychiatric hospital closure. Nick Ardagh-Walter et al 139-141

Survey of locked facilities in Scottish psychiatric hospitals. Alan Smith 77-79

see also Abbasiah, Bexley, Day hospitals, Guy's, Holloway Sanatorium, In-patients and Special hospitals

Hostels. Health: survey of hostel dwelling women. S. V. L. Marriott (Research Unit) et al 618-621

Hyponatraemia

Psychotropics. Robyn McAskill and David Taylor (Drug information quarterly) 33-35

SSRI prescribing in the elderly: caution required. Gillian Pinner et al (C) 376. Catherine Andrews (C) 376

\section{Incapacity Benefit. Philip D. Marshall (C) 242}

In-patients

Characteristics of patients admitted following parasuicide. Polash Shajahan et al 695-698

Concerns about their children - what the parents say. Fiona Stormont et al 495-497

Emergency admissions to a regional adolescent unit. Andrew Cotgrove 604-608

Group psychotherapy: survey of staff and patients. Fiona $\mathrm{S}$. Clunie 13-15

Is there a real need for a short-stay unit in Al Ain, United Arab Emirates? Tewfik K. Daradkeh et al (Briefing) 237-239 
London bed fever. Paul Mallett and Robin Powell (C) 584

Psychiatric beds attached to a community mental health centre. Jed Boardman et al 202-204

Safety and security: survey of female psychiatric in-patients. Fiona Barlow and Paul Wolfson 270-272

Study of effects of constant observation. Olakunle Ashaye et al 145-147

Taking a sexual history. Swaran P. Singh and Andrew J. Beck 99-101

Without psychosis. Characteristics. Implications for service provision and recognition of personality disorder. J. H Dowson et al 553-556

see also Community support bed units, Hospitals and Psychiatric intensive care units

Inquiries

Culture of enquiry. John Cooney et al (C) 57. C. Thompson (Registrar) (C) 241

Who needs them? Matt Muijen (Editorial) 132-133. Commentary. Adrian Grounds (Editorial) 134-135. Michael Howlett (C) 583-584

Internet

Irish Division website 736

Psychiatry and the WWW: some implications. C. Senior et al (Computers in psychiatry) 775-778

Psychiatry: survey of an OCD mailing list. Dan J. Stein 95-98

Interpreters. Investigation of the adequacy of psychiatric interviews conducted through an interpreter. Saced Farooq $e t$ al 209-213

Interviews. Investigation of the adequacy of psychiatric interviews conducted through an interpreter. Saeed Farooq $e$ al 209-213

Interviews

Bill Boyd in converstion with David Tait 769-774

Thomas Szasz in conversation with Alan Kerr 39-44

Inventions. Psychotic patients and patent applications. David V. James and Paul L. Gilluley 764-768

Irish. Health research on the Irish in Britain. Gerard Leavey et al (Editorial) 739-740

Irish Republic

Psychiatric trainees' research experiences and activities in the Eastern region. John Quinn and David Meagher (Education) 367-368

White Paper on a new Mental Health Act. Response of the Irish Division of the Royal College of Psychiatrists. Marcus Webb (Chairman, Irish Division) (Royal College) 307-311

Job-sharing

Claire Hilton (C) 243-244

Register (Inside back cover) June No. 6

Journal clubs. Evidence-based medicine: survey of participants' views. James P. Warner and Michael King (Editorial) 532-534

Journals

Analysis of psychotropic drug advertising. John Quinn et al 597-599

Anthropology and Medicine 736

Autism: The International Journal 527

Current Awareness in Forensic Mental Health 672

Signpost 527

Junior doctors

Safety awareness and provisions for their safety in the workplace. Helen Chubb 80-83

Training in the theory and practice of ECT. Richard Duffett (Research Unit) and Paul Lelliott (Director, Research Unit) (Trainees' forum) 563-565

see also Trainees

Keyworkers. Responsible medical officers: conflict of roles Ikechukwu Obialo Azuonye (C) 661-662
Language

Investigation of the adequacy of psychiatric interviews conducted through an interpreter. Saeed Faroog et al 209-213

see also Terminology

Learning disabilities

Burden Research Prize 736

Dr Blake Marsh and the Blake Marsh Lectures. Kenneth Day and Joze Jancar 26-29

Meeting the mental health needs of adults with mild disabilities. Neill Simpson (Royal College) 247

Mental handicap resettlement readmissions. Douglas A. Spencer (C) 60

Monitoring of patients on high dose antipsychotic medication. Kate Sillifant et al 612-614

Psychotropic medication: audit as an alternative to legislation. H. E. J. Miller et al (Audit) 286-289

Saint Vincent Prize 127

Survey of services for adults. Shaun Gravestock and Nick Bouras 197-199

You're on Trial. Sheila Hollins et al (Shaun Gravestock) (Book review) 668

You 're under Arrest. Sheila Hollins et al (Shaun Gravestock) (Book review) 668

Leave of Absence. Community Care Orders. Consultants' views in Scotland. Jacqueline M. Atkinson et al 91-94

Lithium. Monitoring in hospital and general practice. Ann Ryman (Audit) 570-572

Lithuania. Psychiatry: the highest rate of suicide in the world. Rahman Haghighat (Briefing) 716-719

Litigation. Against psychiatrists. John J. Bradley (Editorial) $321-322$

Liver transplants

Providing a psychiatric service to patients. First two years of the Scottish Liver Transplant Unit. John R. Mitchell et al 6-9. Roger Denny et al (C) 461

Psychiatric liaison services to the Scottish Liver Transplant Unit. Sean Lynch and Sukh Lally (C) 517

Locked units see Psychiatric intensive care units

Log books

CTC position on their use in training. Gary Sullivan (Former Chairman, CTC) et al (Trainees' forum) 278-279

Implementation of a $\log$ book for senior house officers undertaking general professional training. John Cox (Dean) (Royal College) 666

London

Bed fever. Paul Mallett and Robin Powell (C) 584

Geoffrey Knight Unit has survived. P. K. Bridges (C) 121-122

Mental health services. David Goldberg (London Commissioner) (Editorial) 65-66

Management. Two courses for senior/specialist registrars. Maureen O'Brien and Gary Sullivan (Education) 229-231

Managers' Reviews. Mental Health Review Tribunals. Reports prepared for them. Phil Davison and Alberto Perez de Albeniz (Audit) 364-366

Masters courses. Or membership courses? Gary Sullivan and lan R. Jones (Education) 449-450

Media

Glossary of television-related symptoms in psychosis. $\mathbf{M}$. G. Smyth 545-546

Psychiatrists' professional opinions to the media. C. Thompson (Registrar) (Royal College) 62

Psychiatrists' professional opinions to the media - revised guidelines. Special Committee on Unethical Psychiatric Practices (Royal College) 62

see also Psychiatry and the media

Medical Action for Global Security (MEDACT). Psychosocial support in the shadow of war. Nancy Cohn and Jack Piachaud (Briefing) 714-715 
Medical records

Evaluation of a client held record introduced by a community mental health team. Anna Stafford and Richard Laugharne 757-759

Sharing them: comparison of general psychiatric patients with somatisation disorder patients. Nick Goddard et al 489-491

Medical students

Core psychiatry for tomorrow's doctors. Working Party of the Education Committee (Royal College) 522-524. Roch Cantwell and John Brewin (C) 786

Implementing the OSCE in Nottingham. John Brewin and Roch Cantwell 30-32

Objective structured clinical examination. 0 . O. Famuyiwa (C) $459-460$

Survey of attitudes to alcohol and alcoholism among future doctors. John J. Sharkey and Diana Patterson 16-18

Medico-legal. Criminal Procedure (Scotland) Act 1995: new legislation for mentally disordered offenders. Derek Chiswick $110-112$

Membership courses. Or masters courses? Gary Sullivan and Ian R. Jones (Education) 449-450

Mental handicap see Learning disabilities

Mental health

Changing media representations. G. Philo (Psychiatry and the media) 171-172

Health economics in mental health. Neil Craig and Cameron Stark 1: Principles 684-686

2: Economic evaluation 687-691

Health research on the Irish in Britain. Gerard Leavey et al (Editorial) 739-740

Implications of detention of asylum seekers in the UK. Christina Pougourides (Editorial) 673-674

International conference on philosophy and mental health. Christopher Howard (Chairman, Special Interest Group in Philosophy) (Briefing) 179-180

Women, mental health and the family. Henrikje Klasen et al (Editorial) 467-468

Mental Health Act 1983

Absolute power of discharge. P. Divall and M. Jelley (C) 304

Approval of doctors under Section 12. C. Thompson (Registrar) (Royal College) 247

Holding powers in accident and emergency departments. $\mathrm{K}$. R. Nicholls 615-617

Independence of medical recommendations. Graeme Yorston (C) 788

Mental Health Act Commission panel 527

Non-conversion of Section 5(2). Boni Iparragirre and Emad Salib (C) 121

Second medical recommendations and good practice. Mark McCartney (C) 58

Section 3 - hidden consequences. M. T. Malcolm et al (C) 461

Section 4 or 5(2). M. T. Malcolm (C) 58

Section 37 Hospital Order and rights of appeal. Eluned Dorkins and Christine Brown (C) 244

Time to amend Section 135. Peter Cutajar and Michele Hampson 640-641

What to write on form 38. I. O. Azuonye (C) 304

Mental Health Descriptors. Combination with HoNOS. R. J. Craig (C) 585

Mental health legislation

Criminal Procedure Act (Scotland) 1995. New legislation for mentally disordered offenders. Derek Chiswick (Medico-legal) 110-112

Hybrid justice: proposals for the mentally disordered in the Crime (Sentences) Bill. Nigel Eastman (Editorial) 129-131

Non-consultant psychiatrists' knowledge of emergency detention procedures in Scotland. Martin S. Humphreys $631-635$
Republic of Ireland: White Paper on a new Mental Health Act. Response of the Irish Division of the Royal College of Psychiatrists. Marcus Webb (Chairman, Irish Division) (Royal College) 307-311

Stephen Carey and David J. Hall (C) 789

Mental Health Review Tribunals

Managers' Reviews. Reports prepared for them. Phil Davison and Alberto Perez de Albeniz (Audit) 364-366

The restricted patient. Herschel Prins (Risk assessment) 102-104

Time for reform? Carole Kaplan and Paul Ralph (Editorial) 257

Mental health services

Alcohol detoxification: postal survey. Meena Agarwal et al 205-208

Attendance rate at an alcohol problem clinic. Imad M. Ali and Andrew J. McBride 343-345

Characteristics of in-patients without psychosis. Implications for service provision and the recognition of personality disorder. J. H. Dowson et al 553-556

Child and adolescent self-poisoning: service-related characteristics. Ashraf Nasr et al 267-269

Consultation-liaison: from dream to reality. Systematic approach to developing service delivery. Frits J. Huyse and Graeme C. Smith (Editorial) 529-531

Counselling and support services for civil emergencies and major incidents. Anne Nightingale et al 486-488 ECT in Scotland. Carol Robertson et al 699-702

For people from black and other ethnic minorities. Dele Olajide and John Cox (Dean) (Royal College) 305

From problems to solutions. Peter Kennedy (Editorial) 593-594

Geoffrey Knight Unit has survived. P. K. Bridges (C) 121-122

Highly specialised services. R. P. Snaith (C) 59

Injecting some audit into substance misuse services. Beelin Baxter et al (Audit) 360-363

Liaison services to the Scottish Liver Transplant Unit. Sean Lynch and Sukh Lally (C) 517

London. David Goldberg (London Commissioner) (Editorial) 65-66

Long-term psychiatric care in Papua New Guinea. Fiona S. Noble (Briefing) 113-116

Meeting the mental health needs of adults with mild learning disabilities. Neill Simpson (Royal College) 247

Newcastle Clozapine Clinic. Sandra L. Tough et al 492-494

NEWPIN: an opportunity for positive change. Myra Gurr and Anne Hansen (Women's mental health) 480-482

Non-attendance at clinics. Simon Smith et al (C) 303

Old age psychiatry in Wolverhampton 1995 to 1996. David Jolley et al (Audit) 503-505

Predicting attendance at child and adolescent psychiatry clinics. K. Weir (C) 243

Providing a psychiatric service to liver transplant patients. John R. Mitchell et al 6-9. Roger Denny et al (C) 461

Provision for elderly people with long-term functional illness. S. Green et al 353-357

Psychiatric services in Myanmar. Khin-Maung-Zaw (History of psychiatry) 506-509

Psychosurgery: description and outcome study of a regional service. R. P. Snaith et al (Audit) 105-109

'Reading model': an integrated psychotherapy service. Jane Knowles 84-87

Survey of services for adults with learning disabilities. Shaun Gravestock and Nick Bouras 197-199

Task force to review services for drug misusers. Duncan Raistrick (Editorial) 595-596

Twenty-four hour nursed care for people with severe and enduring mental illness. Frank Holloway (Editorial) 195-196

Twenty-four hour psychiatric services. Jacqueline $M$. Atkinson (C) 123

Volunteer project for elderly people with mental health problems. Jon Spear et al 401-404 
Workload and child sexual abuse: an argument for join commissioning. Mary Cole and Margaret Vereker 414-417

see also Community mental health teams, General practice and Hospitals

Mental illness

In Goa, India. Vikram Patel (Briefing) 299-301

Less severe. Samuel I. Cohen (C) 57

Mental disorders and genetics: ethical enquiry 318

Service provision for elderly people with long-term functional illness. S. Green et al 353-357

Suicide in the severely mentally ill. Sue Jackson et al (C) 59

Twenty-four hour nursed care for people with severe and enduring mental illness. Frank Holloway (Editorial) 195-196

Mentally disordered offenders

Criminal Procedure (Scotland) Act 1995: new legislation. Derek Chiswick (Medico-legal) 110-112

Hybrid justice: proposals in the Crime (Sentences) Bill. Nigel Eastman (Editorial) 129-131

Stalking the stalkers. Zaffar Ul-Hassan and Joan Rutherford (C) 787-788

Survey of young offenders in a regional secure unit. C. Lengua et al 535-537

You're on Trial. Sheila Hollins et al (Shaun Gravestock) (Book review) 668

You're under Arrest. Sheila Hollins et al (Shaun Gravestock) (Book review) 668

Mortality

Council Report. The association between antipsychotic drugs and sudden death. Working Party on the Association Between Antipsychotic Drugs and Sudden Death (Royal College) 730-732

Unexpected deaths in psychiatry. Jeremy Holmes (C) 187-188 see also Suicide

MRCPsych

Forthcoming changes to the Part II Examination. R. H. S. Mindham (Chief Examiner) (Royal College) 248

Part II examination: proposed Critical Review Paper. Critical Review Paper Working Party (Royal College) 381-382

Participating: the patients' experience. Darina Sloan et al (Education) 646-648

The rush? Harvey Rees et al (C) 517-518

see also Royal College: Examinations

Music

Boléro unravelled: a case of musical perseveration. Eva M Cybulska (Psychiatry and the media) 576-577

Don't give up your day job. Rob Poole (Outside working hours) 454-455

Myanmar (formerly Burma). Psychiatric services. KhinMaung-Zaw (History of psychiatry) 506-509

National Health Service

Criteria for appointment to a consultant post in psychiatry in the UK (Royal College) 520-521

Future directions of psychotherapy in the NHS: adaptation or extinction? Kate Lockwood (Briefing) 180

Notes of guidance for College representatives on NHS advisory consultant and honorary consultant appointments committees in the UK (Royal College) 519-520

Needs assessment

Needs Assessment in General Practice. S. J. Gillam and S. A. Murray (eds) (Tony Kendrick) (Book review) 671

Who's assessing needs-led assessment? Peter H. Dick $e t$ al (Audit) 290-293

Netherlands

Postgraduate training in psychiatry. Walter P. Bouman (C)

Psychiatric training. Jim van Os (C) 58
Tardive dyskinesia: risk disclosure and informed consent. Walter Pierre Bouman and Jon Arcelus-Alonso (C) 302

Neuroleptics

Choice in epilepsy. Harry McConnell et al (Drug information quarterly) 642-645

Professional attitudes in the UK towards maintenance therapy in schizophrenia. D. A. W. Johnson and J. G. C. Rasmussen 394-397

Staff perception on reduction of medication in patients with chronic schizophrenia. A. Thomas et al 692-694

see also Antipsychotics

Neurosurgery see Psychosurgery

Newcastle Clozapine Clinic. Sandra L. Tough et al 492-494

NEWPIN. An opportunity for positive change. Myra Gurr and Anne Hansen (Women's mental health) 480-482

New Zealand. A trainee's paradise? K. Courtenay (C) 123

Nietzsche. Madness as literature. Eva M. Cybulska (Psychiatry and the media) 510-511

Non-attendance

At clinics. Simon Smith et al (C) 303

Attendance rate at an alcohol problem clinic. Imad M. Ali and Andrew J. McBride 343-345

Predicting attendance at child and adolescent psychiatry clinics. K. Weir (C) 243

Nordic Academy for Advanced Study (NorFA). Networking.

M. Clarke et al (Trainees' forum) 501-502

Nottingham. Implementing the OSCE. John Brewin and Roch Cantwell 30-32

Nursery observation. In the training of child psychiatry registrars. Alicia Etchegoyen and Joanne Stubley 156-159 Nurses

Their help in psychiatric out-patient clinics. C. Brooker and S. Read (Editorial) 675-676. Philip Meats and Terry Ashton 677-679

see also Community paediatric nursing teams and Community psychiatric nurses

\section{Obituaries}

Brooksbank, Donald John by J. J. Bradley 383

Downham, Edward Townley by M. A. Launer 191

Emery, Ralph by Noel I. Lavin 799

Griffiths, Alwyn Byron by M. A. Hill 312

Hare, Edward Henry by John Crammer 312-315

Kirman, Brian Herbert by W. Alan Heaton-Ward 383-384

Lack, Christopher Cheyne 126

Le Couteur, Norman Boyce by David Tidmarsh 253-254

Leiberman, David Monas by Henry R. Rollin 63

McWhinnie, James Barr by Anthony James 799-800

Millar, William Malcolm by John Birtchnell and Douglas Haldane 733-734

Rosen, Ismond by Hugh Freeman 252-253

Sutherland, Sinclair Stewart by Bob Davidson 525

Venkateswarlu, Tamirisa by Isaac Kunguru Mutiboko 667

Warren, Alfred James by Estelle H. Warren 525-526

Objective structured clinical examination (OSCE)

Implementation in Nottingham. John Brewin and Roch Cantwell 30-32

O. O. Famuyiwa (C) $459-460$

Obsessive-compulsive disorder. Psychiatry on the Internet: survey of a mailing list. Dan J. Stein 95-98

Occupational health services. Doctors. Kit Harling (C) 241-242

Occupational therapists. Community psychiatric nurses. Survey of roles. Pam Filson and Tony Kendrick 70-73

Old age see Elderly

Out-patients

HoNOS v. GP opinion in a shifted clinic. John R. Taylor and Greg Wilkinson 483-485 
Nurses' help in psychiatric out-patient clinics. C. Brooker and S. Read (Editorial) 675-676. Philip Meats and Terry Ashton 677-679

On 'higher dose' antipsychotics. John R. Taylor and lan B. Cookson (Audit) 445-448

Outside working hours

Don't give up your day job. Rob Poole 454-455

The sweet smell of successful psychiatry. J. R. King 456-458

Overseas doctors. Postgraduate training and overseas experience. Zubin Bhagwager (C) 242-243

Oxford University Department of Psychiatry. 1969 to 1996. Michael Gelder and Richard Mayou 328-330

\section{Paediatrics}

In child and adolescent psychiatric training. Oonagh Bradley (Education) 294-296

Psychological support for a community nursing team. Gill Salmon and Anne Marie Connor 350-352

Panic disorder. Step by step: helping yourself to cope with panic. Helen Kennerley (Video review) 118-119

Papua New Guinea. Long-term psychiatric care. Fiona S. Noble (Briefing) 113-116

Parasuicide see Deliberate self-harm

Patent applications. Psychotic patients. David V. James and Paul L. Gilluley 764-768

Patients

Incapacity Benefit. Philip D. Marshall (C) 242

Living in the Community. Diana Rose (Tom Burns) (Book review) 670

Long-term medication in depot clinics and rights. Nigel Eastwood and Robert Pugh 273-275

Participating in the MRCPsych: their experience. Darina Sloan et al (Education) 646-648

Patient or polyp? O. Daly (C) 60

A patient's story. Tricia Adams (Briefing) 438-439

Psychiatric advance directives: reconciling autonomy and non-consensual treatment. Adina Halpern and George Szmukler (Editorial) 323-327

The psychiatrist, the patient, their relationship and the movies. Jacqueline M. Atkinson (Psychiatry and the media) 369-370

Risk management: from patient to client. Paul Bowden (Risk assessment) 36-38

Safety and security: survey of female psychiatric in-patients. Fiona Barlow and Paul Wolfson 270-272

Performance art. Razor head. Marina Abramovic. Sean Spence (Psychiatry and the media) 53-55

Perfumery. The sweet smell of successful psychiatry. J. R King (Outside working hours) 456-458

Perseveration. Boléro unravelled: a case of musical perseveration. Eva M. Cybulska (Psychiatry and the media) 576-577

Personality disorder. Characteristics of in-patients without psychosis. Implications for service provision and recognition. J. H. Dowson et al 553-556

Personal view

The dispensable psychiatrist. John Kellett 581-582

Skit. Victor Harris 512-513

Philosophy

International conference on philosophy and mental health. Christopher Howard (Chairman, Special Interest Group in Philosophy) (Briefing) 179-180

Nietzsche: madness as literature. Eva M. Cybulska (Psychiatry and the media) 510-511

Phlebotomists. Not always a good thing. G. E. P. Vincenti (C) 661

Politics

Negative political campaigning. Evidence from the psychological literature: does it work? Nicholas Beecroft (Psychiatry and the media) 297-298

Of psychiatry. J. W. T. Lovett (C) 377
Postnatal depression. Knowledge of the Edinburgh Postnatal Depression Scale among psychiatrists and GPs. Peter Aitken and Robin Jacobson 550-552

Prisons. Training in prison psychiatry. Eluned Dorkins (Trainees ' forum) 52

Prizes

Burden Research 736

Saint Vincent 127

see also Royal College: Prizes and awards

Psychiatric advance directives. Reconciling autonomy and non-consensual treatment. Adina Halpern and George Szmukler (Editorial) 323-327

Psychiatric intensive care units

Hot beds of general psychiatry. National survey of units. M. Dominic Beer et al 142-144. Sean A. Spence (C) 515-516. M. Dominic Beer et al (Authors' reply) (C) 516

Survey of locked facilities in Scottish psychiatric hospitals. Alan Smith 77-79

Psychiatrists

Communication with GPs. Andrew Blakey et al 622-624

The dispensable psychiatrist. John Kellett (Personal view) 581-582

GPs. Knowledge of Edinburgh Postnatal Depression Scale. Peter Aitken and Robin Jacobson 550-552

Litigation against psychiatrists. John J. Bradley (Editorial) 321-322

Loose talk: the media and ethics. Philip Timms (Psychiatry and the media) 573-575

Non-consultant psychiatrists' knowledge of emergency detention procedures in Scotland. Martin S. Humphreys 631-635

Politics of psychiatry. J. W. T. Lovett (C) 377

Professional attitudes in the UK towards neuroleptic maintenance therapy in schizophrenia. D. A. W. Johnson and J. G. C. Rasmussen 394-397

Professional opinions to the media. C. Thompson (Registrar) (Royal College) 62

Professional opinions to the media - revised guidelines. Special Committee on Unethical Psychiatric Practices (Royal College) 62

The psychiatrist, the patient, their relationship and the movies. Jacqueline M. Atkinson (Psychiatry and the media) 369-370

Should they support CPA, guidelines and routine outcome measurement? Paul Lelliott (Director, Research Unit) (Editorial) 1-2. John M. Eagles (C) 377

Psychiatry

Core psychiatry for tomorrow's doctors. Working Party of the Education Committee (Royal College) 522-524. Roch Cantwell and John Brewin (C) 786

The death penalty. Rob Ferris 746-748. Invited commentary. Peter Hodgkinson 749-750

In Lithuania: the highest rate of suicide in the world. Rahman Haghighat (Briefing) 716-719

In Vietnam: a personal impression. John Wallace 779-780

Unexpected deaths. Jeremy Holmes (C) 187-188

The WWW: some implications. C. Senior et al (Computers in psychiatry) 775-778

Psychiatry and the media

Beckett: portraits of the artist in exile. Roisin Kemp and Josephine Loftus 656-658

Bolero unravelled: a case of musical perseveration. Eva $\mathbf{M}$ Cybulska 576-577

Changing media representations of mental health. G. Philo $171-172$

Conflicts of a 90-year-old transsexual. To be, or not to be? Yong-Lock Ong and Pam Davies 720-722

Loose talk: psychiatrists, the media and ethics. Philip Timms 573-575

Negative political campaigning. Evidence from the psychological literature: does it work? Nicholas Beecrof 297-298 
Nietzsche: madness as literature. Eva M. Cybulska 510-511 The psychiatrist, the patient, their relationship and the movies. Jacqueline $M$. Atkinson 369-370

Razor head. The performance art of Marina Abramovic. Sean Spence 53-55

Trainspotting and the depiction of addiction. Peter Byrne 173-175

Using the media during Mental Health Week. Rob Kay et al $451-453$

Violent children and the media. Susan Bailey 371-372

Psychiatry in art. Beyond reason: art and psychosis. Robert

Chaplin and Josephine Richards 276-277

Psychodynamics

Counselling and support services for civil emergencies and major incidents. Anne Nightingale et al 486-488

Teaching group and organisational dynamics to psychiatric trainees. R. Cawthra et al (Trainees' forum) 50-51

Psychological debriefing. Psychological care of staff following traumatic incidents at work. Ronan J. Mclvor et al (Briefing) 176-178

Psychosis

Beyond reason: art and psychosis. Robert Chaplin and Josephine Richards (Psychiatry in art) 276-277

Glossary of television-related symptoms. M. G. Smyth 545-546

Patients and patent applications. David V. James and Paul L. Gilluley $764-768$

Psychosurgery

Description and outcome study of a regional service. $R$. P Snaith et al (Audit) 105-109

Geoffrey Knight Unit has survived. P. K. Bridges (C) 121-122

Highly specialised services. R. P. Snaith (C) 59

Neurosurgery for mental disorder in the UK. Chris Freeman (Editorial) 67-69

Psychotherapy

Experience for trainees. John Ging and Lynne M. Drummond (C) 460

Future directions of psychotherapy in the NHS: adaptation or extinction? Kate Lockwood (Briefing) 180

Nursery observation in the training of child psychiatry registrars. Alicia Etchegoyen and Joanne Stubley 156-159

'Reading model'. An integrated service. Jane Knowles 84-87

Trainees. Current practice, perceived importance and the question of lay counsellors. Peter Byrne and David Meagher (Trainees' forum) 707-710

see also Cognitive analytic therapy, Cognitive-behavioura therapy, Counselling, Group therapy and Psychological debriefing

Publications

AIDS Reference Manual. NAM Publications 672

Alcohol and Depression. Leaflet. Defeat Depression Campaign 192

Alzheimer's Disease Society leaflet 527

Anthropology and Medicine. Journal 736

Autism: The International Journal. National Autistic Society and Sage Publications 527

British Migraine Association leaflet 127

The Broken Mirror - Understanding and Treating Body Dysmorphic Disorder. Katherine Phillips. Oxford University Press 318

The Carers' Resource Book for Younger People with Dementia. Alzheimer's Disease Society 127

Child and Adolescent Psychiatry. Teaching pack. Department of Health and Royal College of General Practitioners Mental Health Education Unit 192

College Bye-Laws and Regulations 672

Current Awareness in Forensic Mental Health. Journal 672

Depression: A guide to its recognition and management in general practice. Neurolink 591

Depression in People with Learning Disability. Leaflet. Defeat Depression Campaign and Down's Syndrome Association 192
Directory of Secure Forensic Psychiatric Facilities 527

Domestic Violence - Making a Difference. NCH Action for Children 591

Getting a Good Night's Sleep? Audio tapes. Royal College of Psychiatrists (Inside back cover) June No. 6

How to recognize the early signs of mental distress. Booklet. MIND publications 127

Issues arising from professional conduct complaints. UKCC report 127

The Management of Health and Safety at Work Regulations 1992 - Updated to include changes affecting young people and new and expectant mothers. Leaflet. Health and Safety Executive 672

Manic Depressive Illness. Help is at Hand Leaflet 800

Media and Mental Distress. Greg Philo (ed.). Glasgow Media Group 192

Mental Health and Growing Up. Factsheets. Royal College of Psychiatrists 127

Michelle Finds a Voice. Royal College of Psychiatrists and St George's Hospital Medical School 800

Not Just Sticks and Stones. MIND report 127

Physical Signs of Sexual Abuse in Children (2nd edn). Royal College of Physicians working party report 672

A Policy Framework to Guide the Use of Physical Intervention (Restraint) with Adults and Children with Learning Disabilities and/or Autism. British Institute of Learning Disabilities and National Autistic Society 64

Procedures in General Practice. John Stuart Brown. BMJ Publishing Group 527

Signpost. Journal. Service Development Team (EMI) of Cardiff Community Healthcare NHS Trust 527

Staying Sane. How to make your mind work for you. Raj Persaud. Metro Publishing 591

Transforming Health in London. King's Fund London Commission Report 672

When a Pet Dies. Learning pack. Society for Companion Animal Studies 64

Public attitudes. Using the media during Mental Health Week. Rob Kay et al (Psychiatry and the media) 451-453

Rapid tranquillisation. Are we getting it right? Laura Mannion et al $411-413$

Ravel, Maurice. Boléro unravelled: a case of musical perseveration. Eva M. Cybulska (Psychiatry and the media) 576-577

Reading model. Integrated psychotherapy service. Jane Knowles 84-87

Readmission

Mental handicap resettlement readmissions. Douglas A Spencer (C) 60

Risk factors for acute psychiatric readmission. Mandy Dixon et al 600-603

Recovered memories

False memories of child sexual abuse. Mike Hobbs (Video review) 119

Reported recovered memories of child sexual abuse. Working Group on Reported Recovered Memories of Child Sexual Abuse (Royal College) 663-665

Refugees. Mental health implications of detention of asylum seekers in the UK. Christina Pougourides (Editorial) 673-674

Regional secure units. Survey of young offenders in a unit. C. Lengua et al 535-537

\section{Registrars}

Methods of post allocation. Paul Ramchandani et al (Trainees' forum) 711-713

Nursery observation in the training of child psychiatry registrars. Alicia Etchegoyen and Joanne Stubley 156-159

Research

Health research on the Irish in Britain. Gerard Leavey et al (Editorial) 739-740 
Networking with NorFA. M. Clarke et al (Trainees' forum) $501-502$

Psychiatric trainees' experiences and activities in the Eastern region of Ireland. John Quinn and David Meagher (Education) 367-368

Role in psychiatric training: trainees' perspective. John Farnill Morgan (C) 787

Responsible medical officers. Keyworkers: conflict of roles. Ikechukwu Obialo Azuonye (C) 661-662

Resuscitation. Improving skills in psychiatric hospitals. Tony Winston and Gary Drybala 557-560

Reviews see Book and Video reviews

Risk assessment

Assessment and management of risk in psychiatry: can we do better? Frank Holloway 283-285. A. Morrison (C) 583. Frank Holloway (Author's reply) (C) 583

Assessment of suicide risk. Louis Appleby (Director, National Confidential Inquiry into Suicide and Homicide by People with Mental Illness) (Editorial) 193-194. Rajan Nathan (C) 660. John M. Eagles (C) 660

Clinical risk management: an emerging agenda for psychiatry. David Roy 162-164

Management of suicide risk. H. G. Morgan 214-216

Mental Health Review Tribunal and the restricted patient. Herschel Prins 102-104

Psychiatry: a risky business? Frank Holloway (Series Editor) 36 Risk management: from patient to client. Paul Bowden 36-38

Violent behaviour. George J. Lodge 703-706

Risperidone. Evaluating and improving the quality of prescribing. David Taylor et al 680-683

Rosen, Ismond

(Inside back cover) June No. 6

see also Obituaries

Royal Air Force. Community psychiatry. Julian C. Hughes 418-421. G. E. Reid (C) 786-787

Royal College

Affiliate status. Meetings with doctors in the staff grades George Stein 405-407

Approval of doctors under Section 12 of the Mental Health Act (1983). C. Thompson (Registrar) 247

Archives. Minutes yesterday and today. Margaret Harcourt Williams (Archivist) 589

Assessors. List 190

Bye-Laws and Regulations 672

'Clinical effectiveness'. The College. Robert Kendell (President) (Editorial) 385-386

Confidentiality. Working Party 255

Consultants

Criteria for appointment to an NHS post in psychiatry in the UK 520-521

Notes of guidance for College representatives on NHS advisory consultant and honorary consultan appointments committees in the UK 519-520

Council Reports 730-732, 798

CPD and the Fellowship. Adam Moliver (C) 242

Design a logo for a new campaign 672

Drugs

Council Report. Benzodiazepines: risks, benefits or dependence. A re-evaluation 798

Council Report. The association between antipsychotic drugs and sudden death. Working Party on the Association Between Antipsychotic Drugs and Sudden Death 730-732

Interim statement on anti-dementia drugs. Implications, concerns and policy proposals. Working Group of Section for Psychiatry of Old Age 586-587

Elections 64

Annual 246-247

Approved nominations to the Fellowship and Membership under Bye-Law III 2(ii) and approved Affiliates 462
Honorary Fellows 379

Anne Dean (Head of Postgraduate Educational

Services) 590

Election and introduction 792-797

President 61

Enduring personality changes after membership. Skit. Victor Harris (Personal view) 512-513

Ethnic minorities. Mental health services for people from black and other ethnic minorities. Dele Olajide and John Cox (Dean) 305

Examinations

Forthcoming changes to the MRCPsych Part II. R. H. S. Mindham (Chief Examiner) 248

MRCPsych Part II: proposed Critical Review Paper.

Critical Review Paper Working Party 381-382

Results 249-251, 727-729

Inquiries. Culture of inquiry. C. Thompson (Registrar) (C) 241

Irish Division

Republic of Ireland: White Paper on a new Mental Health Act. Response. Marcus Webb (Chairman, Irish Division) 307-311

Website 736

Learning disabilities. Meeting the mental health needs of adults with mild disabilities. Neill Simpson 247

Library and Information Service

Library stock. E. M. Nokes (Librarian) 125

Photocopy service. Library staff 463

Recent donations 61, 590

Media

Psychiatrists' professional opinions. C. Thompson (Registrar) 62

Psychiatrists' professional opinions - revised guidelines. Special Committee on Unethical Psychiatric Practices 62

Meetings

Joint meeting with the American Board of Psychiatry and Neurology (ABPN), 6 July 1996. Anne Dean (Head of Postgraduate Educational Services) 306

Twenty-sixth Annual, July 1997.790-791

Winter 1997. 379-380

Occasional Paper. Annual Census of Psychiatric Staffing. 1995. 125

Prizes and awards

Laughlin Prize 251, 728

Plain English Campaign Award for College 127

Scottish Division Annual Awards 1996. 318

Reported recovered memories of child sexual abuse. Recommendations for good practice and implications for training, continuing professional development and research. Working Group on Reported Recovered Memories of Child Sexual Abuse 663-665

Scottish Division. Annual Awards 1996. 318

Sick doctors. Examiners and assessors. S. A. Mann 189

Special Interest Groups

Inaugural meeting of the Special Interest Group for Women in Psychiatry. Anne Cremona (Chairman, Special Interest Group for Women in Psychiatry) (Briefing) 179

International conference on philosophy and mental health. Christopher Howard (Chairman, Special Interest Group in Philosophy) (Briefing) 179-180

Statement on continuing care for older adults with psychiatric disorder 588

Training and education

Core psychiatry for tomorrow's doctors. Working Party of the Education Committee 522-524. Roch Cantwell and John Brewin (C) 786

Implementation of a log book for senior house officers undertaking general professional training. John Cox (Dean) 666

Royal Colleges. Fellowships. Denis Pereira Gray (C) 120-121 
Safety and Efficacy Register. New interventional procedures 64 Safety issues

Awareness among junior psychiatrists and provisions for their safety in the workplace. Helen Chubb 80-83

Increasing staff safety. Richard A. Powell and Brian Kidd (C) 187 Safety and security: survey of female psychiatric in-patients. Fiona Barlow and Paul Wolfson 270-272

Schedules for Clinical Assessment in Neuropsychiatry (SCAN). Description of primary delusions: confusion in standard texts and among clinicians. Imad M. Ali (C) 660-661

Schizophrenia

Genetic linkage studies 255

Impact on women who care for those with schizophrenia. Marcia Scazufca and Elizabeth Kuipers (Women's mental health) 469-471

Mental Health Award available to clinicians 736

Options for Improving Patient Care in Schizophrenia. Hugh Freeman (ed.) (D. A. W. Johnson) (Book review) 669

A patient's story. Tricia Adams (Briefing) 438-439

Professional attitudes in the UK towards neuroleptic maintenance therapy. D. A. W. Johnson and J. G. C. Rasmussen 394-397

Staff perception on reduction of medication in chronic patients. A. Thomas et al 692-694

Scotland

Consultants' views of Leave of Absence and Community Care Orders. Jacqueline M. Atkinson et al 91-94

Criminal Procedure (Scotland) Act 1995: new legislation for mentally disordered offenders. Derek Chiswick (Medico-legal) 110-112

ECT. Carol Robertson et al 699-702

Mental health legislation. Stephen Carey and David J. Hall (C) 789

Non-consultant psychiatrists' knowledge of emergency detention procedures. Martin S. Humphreys 631-635

Providing a psychiatric service to liver transplant patients. First two years of the Scottish Liver Transplant Unit. John R. Mitchell et al 6-9

Psychiatric liaison services to the Scottish Liver Transplant Unit. Sean Lynch and Sukh Lally (C) 517

Survey of locked facilities in psychiatric hospitals. Alan Smith 77-79

Seclusion

The doctor. John Crammer (C) 515. M. F. Okhai and P M. McLaren (Authors' reply) (C) 515

Re-evaluation of the role of trainee psychiatrists in secluding general adult psychiatric patients. M. F. Okhai and $P$. M. McLaren (Trainees' forum) 227-228

Selective serotonin reuptake inhibitors (SSRIs). Prescribing in the elderly: caution required. Gillian Pinner et al (C) 376. Catherine Andrews (C) 376

Self-harm see Deliberate self-harm

Self-referrals. To a large psychiatric hospital. Nicola Gray and Emad Salib 751-753

Senior house officers. Implementation of a log book for senior house officers undertaking general professional training. John Cox (Dean) (Royal College) 666

Senior registrars

Child and adolescent psychiatry. Role conflict and barriers to learning. D. M. Eminson and J. M. Green 339-342

Two management courses for senior/specialist registrars Maureen O'Brien and Gary Sullivan (Education) 229-231

Visits programme for forensic senior registrars. Akintunde Akinkunmi (Trainees' forum) 280-282

Sexual abuse

Case report. Richard Hodgson (C) 123-124

False memories of child sexual abuse. Mike Hobbs (Video review) 119

Group therapy in the treatment of childhood sexual abuse. Janet Boakes 754-756
Negative views of the mother after childhood sexual abuse. Janet D. Feigenbaum (Women's mental health) 477-479

Reported recovered memories of child sexual abuse. Working Group on Reported Recovered Memories of Child Sexual Abuse (Royal College) 663-665

Safety and security: survey of female psychiatric in-patients. Fiona Barlow and Paul Wolfson 270-272

Workload and child sexual abuse: an argument for joint commissioning. Mary Cole and Margaret Vereker 414-417

Sexual history. Taking a history from in-patients. Swaran P. Singh and Andrew J. Beck 99-101

Short-stay units. Is there a real need for a unit in Al Ain, United Arab Emirates? Tewfik K. Daradkeh et al (Briefing) 237-239

Sick doctors

Examiners and assessors. S. A. Mann (Royal College) 189 Occupational health services. Kit Harling (C) 241-242

Request for information. D. M. Hambridge (C) 245

Single sex wards. Case report. Richard Hodgson (C) 123-124

Somatisation disorder. Sharing medical records: comparison of patients with general psychiatric patients. Nick Goddard et al 489-491

Special hospitals. Costs of physical health care for selfinjuring patients. Mark Swinton and Sarah Smith 538-541

Special Interest Groups

Inaugural meeting of the Special Interest Group for Women in Psychiatry. Anne Cremona (Chairman, Special Interest Group for Women in Psychiatry) (Briefing) 179

International conference on philosophy and mental health Christopher Howard (Chairman, Special Interest Group in Philosophy) (Briefing) 179-180

Speciality tutors. Role in the training of junior doctors in psychiatry. Patricia Hughes (Trainees' forum) 435-437 Stafi

Annual Census of Psychiatric Staffing. 1995. Occasional Paper (Royal College) 125

Attitudes to a psychiatric hospital closure. Nick ArdaghWalter et al 139-141

Clinical involvement by medical secretaries and receptionists. Simon Thacker (C) 122

Effects of education on attitudes to deliberate self-harm. Gill Turnbull and Trudie Chalder 334-335

Helping people grieve - the role of the health worker. Mark Aveline (Video review) 118

Increasing their safety. Richard A. Powell and Brian Kidd (C) 187

In-patient group psychotherapy: survey of staff and patients. Fiona S. Clunie 13-15

Perception on reduction of medication in patients with chronic schizophrenia. A. Thomas et al 692-694

Psychological care following traumatic incidents at work Ronan J. Mclvor et al (Briefing) 176-178

Staff grade psychiatrists

Meetings: development of affiliate status. George Stein 405-407

View from the inside. Aileen Blower and Diane Lusman $151-153$

Stalkers. Stalking them. Zaffar Ul-Hassan and Joan Rutherford (C) 787-788

Substance misuse see Alcohol and Drug misuse

Suicide

Assessment of risk. Louis Appleby (Director, National Confidential Inquiry into Suicide and Homicide by People with Mental Illness) (Editorial) 193-194. Rajan Nathan (C) 660. John M. Eagles (C) 660

Friday the 13th and fatal self-harm. Emad Salib et al (C) 459

In the severely mentally ill. Sue Jackson et al (C) 59

Management of risk. H. G. Morgan (Risk assessment) 214-216

Psychiatry in Lithuania: the highest rate in the world. Rahman Haghighat (Briefing) 716-719

Unexpected deaths in psychiatry. Jeremy Holmes (C) 187-188

see also Deliberate self-harm 
Supervision. Educational supervision sessions between consultants and trainees. I. O. Azuonye 154-155. Peter M. Herriot and Kamaldeep Bhui (C) 785-786

Supervision registers

Clinical risk management: an emerging agenda for psychiatry. David Roy (Risk assessment) 162-164

Operational problems. Jonathan H. Dowson et al (C) 122

Syndrome of inappropriate antidiuretic hormone secretion (SIADH)

Psychotropics and hyponatraemia. Robyn McAskill and David Taylor (Drug information quarterly) 33-35

SSRI prescribing in the elderly: caution required. Gillian Pinner et al (C) 376. Catherine Andrews (C) 376

Szasz, Thomas. In conversation. Alan Kerr (Interview) 39-44

Tarasoff case. The duty to warn third parties. Mark Turner and Michael Kennedy (Editorial) 465-466. Aileen Blower and Mark Cohen (C) 724-725

Tardive dyskinesia

How is it prevented and treated? Denise Duncan et al (Drug information quarterly) 422-425. James G. Longhurst and Erica L. Weiss (C) 723-724. P. Duffey et al (C) 724

Risk disclosure and informed consent in the Netherlands. Walter Pierre Bouman and Jon Arcelus-Alonso (C) 302

Team for the Assessment of Psychiatric Services (TAPS)

Assessment and management of risk: can we do better? A Morrison (C) 583. Frank Holloway (Author's reply) (C) 583

Eleventh Annual Conference. Hugh Freeman (Briefing) 233-234

Television. Glossary of television-related symptoms in psychosis. M. G. Smyth 545-546

Terminology

Description of primary delusions: confusion in standard texts and among clinicians. R. H. McAllister-Williams 346-349. Imad M. Ali (C) 660-661

Greek mythology and medical and psychiatric terminology. Loukas Athanasiadis (History of psychiatry) 781-782

Patient or polyp? O. Daly (C) 60

Trainees

Administration of ECT by trainee psychiatrists. Jonathan Hillam et al (Audit) 217-220

The doctor and seclusion. John Crammer (C) 515. M. F. Okhai and P. M. McLaren (Authors' reply) (C) 515

Educational supervision sessions with consultants. I. O. Azuonye 154-155. Peter M. Herriot and Kamaldeep Bhui (C) 785-786

Financial implications of Calman changes. Zubin Bhagwagar (C) 784-785. R. E. Kendell (President) (C) 785

In the specialities. Simon Thacker (C) 375. J. P. Wattis (Chairman, Section for Psychiatry of Old Age) (C) 375

New Zealand - a trainee's paradise? K. Courtenay (C) 123

Psychotherapy experience. John Ging and Lynne $M$. Drummond (C) 460

Rapid tranquillisation: are we getting it right? Laura Mannion et al $411-413$

Research experiences and activities in the Eastern region of Ireland. John Quinn and David Meagher (Education) 367-368

Role of research in psychiatric training: trainees' perspective. John Farnill Morgan (C) 787

see also Junior doctors

Trainees' forum

Collegiate Trainees' Committee. Gary Sullivan 358-359

CTC position on the use of logbooks in training. Gary Sullivan (Former Chairman, CTC) et al 278-279

Fourth European Trainees' Forum. Peter Cornwall and Laurence Sheldon (CTC) (Briefing) 117
Junior doctors' training in the theory and practice of ECT. Richard Duffett (Research Unit) and Paul Lelliott (Director, Research Unit) 563-565

Methods of registrar post allocation. Paul Ramchandani et al 711-713

Networking with NorFA. M. Clarke et al 501-502

1996 Trainees' Forum. Peter Cornwall (CTC) (Briefing) 47

Psychotherapy and trainees. Current practice, its perceived importance and the question of lay counsellors. Peter Byrne and David Meagher 707-710

Re-evaluation of the role of trainee psychiatrists in secluding general adult psychiatric patients. M. F. Okhai and P. M. McLaren 227-228

Role of the speciality tutor in the training of junior doctors in psychiatry. Patricia Hughes 435-437

Teaching group and organisational dynamics to psychiatric trainees. R. Cawthra et al 50-51

Training in prison psychiatry. Eluned Dorkins 52

Visits programme for forensic senior registrars. Akintunde Akinkunmi 280-282

Training

Flexible training in psychiatry. Ilfra Goldberg (Editorial) 387-388

Implementation of a log book for senior house officers undertaking general professional training. John Cox (Dean) 666

Job-sharing. Claire Hilton (C) 243-244

Nursery observation in the training of child psychiatry registrars. Alicia Etchegoyen and Joanne Stubley 156-159

Postgraduate training and overseas experience. Zubin Bhagwager (C) 242-243

Postgraduate training in psychiatry. Walter P. Bouman (C) 120. John Sandford (C) 120

Psychiatric training in the Netherlands. Jim van Os (C) 58

Role conflict and barriers to learning for senior registrars in child and adolescent psychiatry. D. M. Eminson and J. M. Green 339-342

The rush for the MRCPsych? Harvey Rees et al (C) 517-518 see also Education

Trainspotting (film). Depiction of addiction. Peter Byrne (Psychiatry and the media) 173-175

Transsexualism. Conflicts of a 90 -year-old. To be, or not to be? Yong-Lock Ong and Pam Davies (Psychiatry and the media) $720-722$

Trauma

Counselling and support services for civil emergencies and major incidents. Anne Nightingale et al 486-488

Psychological care of staff following traumatic incidents at work. Ronan J. Mclvor et al (Briefing) 176-178

Psychosocial support in the shadow of war. Nancy Cohn and Jack Piachaud (Briefing) 714-715

Trinidad and Tobago. Cocaine and social transformation. Hari Maharajh (Briefing) 184-185

Twenty-four hour nursed care. For people with severe and enduring mental illness. Frank Holloway (Editorial) 195-196

Uganda. Rebuilding psychiatry. Jed Boardman and Emilio Ovuga (Briefing) 649-655

\section{Undergraduates see Medical students}

United Arab Emirates. Is there a real need for a short-stay unit in Al Ain? Tewfik K. Daradkeh et al (Briefing) 237-239

United Kingdom

Criteria for appointment to an NHS consultant post in psychiatry (Royal College) 520-521

Mental health implications of detention of asylum seekers. Christina Pougourides (Editorial) 673-674

National survey of psychiatric intensive care units. $M$. Dominic Beer et al 142-144. Sean A. Spence (C) 515516. M. Dominic Beer et al (Authors' reply) (C) 516 
Neurosurgery for mental disorder. Chris Freeman (Editorial) 67-69

Notes of guidance for College representatives on NHS advisory consultant and honorary consultant appointments committees (Royal College) 519-520

Professional attitudes towards neuroleptic maintenance therapy in schizophrenia. D. A. W. Johnson and J. G. C. Rasmussen 394-397

United Kingdom Central Council for Nursing, Midwifery and Health Visiting 672

see also Britain

United States

Joint meeting between the Royal College of Psychiatrists and the American Board of Psychiatry and Neurology (ABPN), 6 July 1996. Anne Dean (Head of Postgraduate Educational Services) (Royal College) 306

Psychiatry and the death penalty. Rob Ferris 746-748. Invited commentary. Peter Hodgkinson 749-750

Valproate. Carbamazepine. Doses in bipolar affective disorder David Taylor and Denise Duncan (Drug information quarterly) 221-223. J. B. Grace and A. H. Young (C) 784 David Taylor and Denise Duncan (Authors' reply) (C) 784

Video reviews

False memories of child sexual abuse. Mike Hobbs 119

Helping people grieve - the role of the health worker. Mark Aveline 118

Step by step: helping yourself to cope with panic. Helen Kennerley 118-119

Vietnam. Psychiatry: a personal impression. John Wallace 779-780

Vignettes

Humble pie. Henry R. Rollin 316-317

In my Father's house are many mansions. Henry R. Rollin 514

A novel therapeutic agent. J. B. Collinson 56

Reparanoitee. Seymour Spencer 378

The smile in endogenous depression. Seymour Spencer 659

Violence

Drug management of acute behavioural disturbance. SiriAnn Robling et al (Audit) 440-444

Tarasoff and the duty to warn third parties. Mark Turner and Michael Kennedy (Editorial) 465-466. Aileen Blowe and Mark Cohen (C) 724-725

Violent children and the media. Susan Bailey (Psychiatry and the media) 371-372

see also Rapid tranquillisation, Risk assessment, Safety issues, Seclusion and War

Volunteers. Project for elderly people with mental health problems. Jon Spear et al 401-404

War. Psychosocial support in the shadow of war. Nancy Cohn and Jack Piachaud (Briefing) 714-715

Wolverhampton. Old age psychiatry 1995 to 1996. David Jolley et al (Audit) 503-505

Women

Flexible training in psychiatry. Ilfra Goldberg (Editorial) 387-388

Health in hostels: a survey. S. V. L. Marriott (Research Unit) et al 618-621

Impact on women who care for those with schizophrenia. Marcia Scazufca and Elizabeth Kuipers (Women's mental health) 469-471

Inaugural meeting of the Special Interest Group for Women in Psychiatry. Anne Cremona (Chairman, Special Interest Group for Women in Psychiatry) (Briefing) 179

Mental health, and the family. Henrikje Klasen et al (Editorial) 467-468
Negative views of the mother after childhood sexual abuse. Janet D. Feigenbaum (Women's mental health) 477-479

NEWPIN: an opportunity for positive change. Myra Gurr and Anne Hansen (Women's mental health) 480-482

Safety and security: survey of female psychiatric in-patients. Fiona Barlow and Paul Wolfson 270-272

Women and children living with HIV infection. Some psychological concerns. Diane Melvin and Lorraine Sherr (Women's mental health) 472-476

Work schemes. Specialist schemes: user satisfaction and costs. Justine Schneider and Angela Hallam 331-333

World Wide Web

Irish Division website 736

Psychiatry and the WWW: some implications. C. Senior et al (Computers in psychiatry) 775-778

Yugoslavia, former. Psychosocial support in the shadow of war. Nancy Cohn and Jack Piachaud (Briefing) 714-715

\section{PART II - CONTRIBUTORS}

Adams, Tricia. A patient's story (Briefing) 438-439

Agarwal, Meena et al. Alcohol detoxification: a postal survey 205-208

Aitken, Peter and Jacobson, Robin. Knowledge of the Edinburgh Postnatal Depression Scale among psychiatrists and general practitioners 550-552

Akinkunmi, Akintunde. A visits programme for forensic senior registrars (Trainees ' forum) 280-282

Al-Adwani, Andrew and Nabi, D. W. CPA: faith or fact (C) 725

Al-Adwani, Andrew and Nabi, Waheed. GPs and the Care Programme Approach (C) 303

Ali, Imad M. Description of primary delusions: confusion in standard texts and among clinicians (C) 660-661

Ali, Imad M. and McBride, Andrew J. Attendance rate at an alcohol problem clinic 343-345

Anderson, Ian see Blakey, Andrew et al 622-624

Andrews, Catherine. SSRI prescribing in the elderly: caution required (C) 376

Appleby, Louis (Director, National Confidential Inquiry into Suicide and Homicide by People with Mental Illness). Assessment of suicide risk (Editorial) 193-194

Arcelus-Alonso, Jon see Bouman, Walter Pierre (C) 302

Ardagh-Walter, Nick et al. Staff attitudes to a psychiatric hospital closure 139-141

Ashaye, Olakunle et al. Study of effects of constant observation of psychiatric in-patients $145-147$

Ashton, Terry see Meats, Philip 677-679

Atakan, Zerrin see Stormont, Fiona et al 495-497

Athanasiadis, Loukas. Greek mythology and medical and psychiatric terminology (History of psychiatry) 781-782

Atkins, Maria (Honorary Secretary, CTC) see Sullivan, Gary (Former Chairman, CTC) et al (Trainees' forum) 278-279

Atkins, Maria et al. Chlorpromazine equivalents: a consensus of opinion for both clinical and research applications (Drug information quarterly) 224-226

Atkinson, Jacqueline M. 24 hour psychiatric services (C) 123

Atkinson, Jacqueline $M$. The psychiatristthe patient, their relationship and the movies (Psychiatry and the media) 369-370

Atkinson, Jacqueline M. et al. Consultants' views of Leave of Absence and Community Care Orders in Scotland 91-94

Aveline, Mark. Helping people grieve - the role of the health worker (Video review) 118

Azuonye, I. O. Educational supervision sessions between consultants and trainees 154-155 
Azuonye, 1. O. What to write on Mental Health Act form 38 (C) 304 Azuonye, Ikechukwu Obialo. Responsible medical officers and keyworkers: conflict of roles (C) 661-662

Bailey, Susan. Violent children and the media (Psychiatry and the media) 371-372

Barlow, Fiona and Wolfson, Paul. Safety and security: a survey of female psychiatric in-patients 270-272

Baxter, Beelin et al. Injecting some audit into substance misuse services (Audit) 360-363

Beck, Andrew J. see Singh, Swaran P. 99-101

Beecroft, Nicholas. Negative political campaigning. Evidence from the psychological literature: does it work? (Psychiatry and the media) 297-298

Beer, M. Dominic et al. Hot beds of general psychiatry. A national survey of psychiatric intensive care units 142-144

Beer, M. Dominic et al. National survey of psychiatric intensive care units (Authors' reply) (C) 516

Bernadt, Morris see Goddard, Nick et al 489-491

Bhagwagar, Zubin. Financial implications of Calman changes in psychiatry $(C)$ 784-785

Bhagwager, Zubin. Postgraduate training and overseas experience (C) 242-243

Bhui, Kamaldeep see Herriot, Peter M. (C) 785-786

Birtchnell, John and Haldane, Douglas. William Malcolm Millar (Obituary) 733-734

Blakey, Andrew et al. Communication between GPs and psychiatrists: the long and short of it 622-624

Blower, Aileen and Cohen, Mark. Tarasoff and the duty to warn third parties (C) 724-725

Blower, Aileen and Lusman, Diane. Staff grade psychiatrists a view from the inside $151-153$

Boakes, Janet. Group therapy in the treatment of childhood sexual abuse 754-756

Boardman, Jed et al. Psychiatric beds attached to a community mental health centre 202-204

Boardman, Jed and Ovuga, Emilio. Rebuilding psychiatry in Uganda (Briefing) 649-655

Bonner, D. see Marriott, S. V. L. (Research Unit) et al 618-62

Bottomley, Clare see Atkins, Maria et al (Drug information quarterly) 224-226

Bouman, Walter P. see Pinner, Gillian et al (C) 376

Bouman, Walter P. Postgraduate training in psychiatry (C) 120

Bouman, Walter Pierre and Arcelus-Alonso, Jon. Tardive dyskinesia: risk disclosure and informed consent in the Netherlands (C) 302

Bouras, N. see Thomas, A. et al 692-694

Bouras, Nick see Gravestock, Shaun 197-199

Bowden, Paul. Risk management: from patient to client (Risk assessment) 36-38

Bradley, J. J. Donald John Brooksbank (Obituary) 383

Bradley, John J. Litigation against psychiatrists (Editorial) 321-322

Bradley, Oonagh. Paediatrics in child and adolescent psychiatric training (Education) 294-296

Brewin, John see Cantwell, Roch (C) 786

Brewin, John and Cantwell, Roch. Implementing the OSCE in Nottingham 30-32

Bridges, P. K. The Geoffrey Knight Unit has survived (C) 121-122

Brittlebank, Andrew and Owens, Julie. Cognitivebehavioural therapy training for junior psychiatric trainees (Education) 169-170

Brooker, C. and Read, S. Nurses' help in psychiatric out-patient clinics: saving time or saving value (Editorial) 675-676

Brown, Christine see Dorkins, Eluned (C) 244

Burgess, Adrian see Atkins, Maria et al (Drug information quarterly) 224-226

Burns, Tom. Living in the Community. Diana Rose (Book review) 670

Burns, Tom and Leibowitz, Judy. The Care Programme Approach: time for frank talking 426-429
Butler, A. see Snaith, R. P. et al (Audit) 105-109

Byrne, Peter. Trainspotting and the depiction of addiction (Psychiatry and the media) 173-175

Byrne, Peter and Meagher, David. Psychotherapy and trainees. Current practice, its perceived importance and the question of lay counsellors (Trainees' forum) 707-710

Caan, Woody see Baxter, Beelin et al (Audit) 360-363

Cameron, Vanessa. Donald John Brooksbank. Note 383

Canterbury, Rachel see McIvor, Ronan J. et al (Briefing) 176-178

Cantwell, Roch see Brewin, John 30-32

Cantwell, Roch and Brewin, John. Core psychiatry for tomorrow's doctors (C) 786

Carey, Stephen and Hall, David J. Mental health legislation (C) 789

Casey, Patricia R. see Quinn, John et al 597-599

Casey, Patricia R. Depression in General Practice. Andrć Tylee et al (Book review') 668-669

Cawthra, R. et al. Teaching group and organisational dynamics to psychiatric trainees (Trainees 'forum) 50-51

Chalder, Trudie see Turnbull, Gill 334-335

Chaplin, Robert and Richards, Josephine. Beyond reason: art and psychosis (Psychiatry in art) 276-277

Chiswick, Derek. The Criminal Procedure (Scotland) Act 1995: new legislation for mentally disordered offenders (Medicolegal) 110-112

Chubb, Helen. Safety awareness among junior psychiatrists and provisions for their safety in the workplace 80-83

Clark, Andrew. High dose antipsychotic prescribing (C) 58-59

Clarke, Grania see Leavey, Gerard et al (Editorial) 739-740

Clarke, M. et al. Networking with NorFA (Trainees' fortum) 501-502

Clunie, Fiona S. In-patient group psychotherapy: a survey of staff and patients 13-15

Cohen, Mark see Blower, Aileen (C) 724-725

Cohen, Samuel I. Less severe mental illness (C) 57

Cohn, Nancy and Piachaud, Jack. Psychosocial support in the shadow of war. Nancy Cohn and Jack Piachaud (Briefing) $714-715$

Cole, Mary and Vereker, Margaret. Workload and child sexual abuse: an argument for joint commissioning 414-417

Collinson, J. B. A novel therapeutic agent (Vignette) 56

Commander, Martin et al. Birmingham community mental health team for the homeless 74-76

Commander, Martin et al. Psychiatric admission for homelesss people: the impact of a specialist community mental health team 260-263

Conlon, Bill see Trezise, Kate 10-12

Connolly, Louise see Mannion, Laura et al 411-413

Connor, Anne Marie see Salmon, Gill 350-352

Cook, C. C. H. see Hughes, J. C. (C) 186

Cookson, Ian B. see Taylor, John R. (Audit) 445-448

Cooney, John et al. The culture of enquiry (C) 57

Cormac, Irene (Vice-Chairman, CTC) see Sullivan, Gary (Former Chairman, CTC) et al (Trainees' forum) 278-279

Cornwall, Peter (Chairman, CTC) see Sullivan, Gary (Former Chairman, CTC) et al (Trainees 'forum) 278-279

Cornwall, Peter (CTC). 1996 Trainees' Forum (Briefing) 47

Cornwall, Peter (CTC) and Sheldon, Laurence (CTC). The Fourth European Trainees' Forum (Briefing) 117

Cotgrove, Andrew. Emergency admissions to a regional adolescent unit: piloting a new service 604-608

Coughlan, A. K. see Snaith, R. P. et al (Audit) 105-109

Courtenay, K. New Zealand - a trainee's paradise? (C) 123

Cox, John (Dean) see Olajide, Dele (Royal College) 305

Cox, John (Dean). Implementation of a log book for senior house officers undertaking general professional training (Royal College) 666

Crabb, Mary see Sillifant, Kate et al 612-614

Craig, Neil and Stark, Cameron. Health economics in mental health. 1: Principles 684-686 
Craig, Neil and Stark, Cameron. Health economics in mental health. 2: Economic evaluation 687-691

Craig, R. J. Combination of HoNOS with Mental Health Descriptors (C) 585

Craig, Tom see Stormont, Fiona et al 495-497

Crammer, John. Edward Henry Hare (Obituary) 312-315

Crammer, John. The doctor and seclusion (C) 515

Crawford, M. J. and Kohen, D. Urgent psychiatric assessment in an inner-city A\&E department 625-626

Cremona, Anne (Chairman, Special Interest Group for Women in Psychiatry). Inaugural meeting of the Special Interes Group for Women in Psychiatry (Briefing) 179

Cribb, Jan see Denny, Roger et al (C) 461

Crimlisk, Helen see Klasen, Henrikje et al (Editorial) 467-468

Cutajar, Peter and Hampson, Michele. Time to amend Section 135. 640-641

Cybulska, Eva M. Boléro unravelled: a case of musical perseveration (Psychiatry and the media) 576-577

Cybulska, Eva M. Nietzsche: madness as literature (Psychiatry and the media) 510-511

Daly, O. Patient or polyp? (C) 60

Daradkeh, Tewfik K. et al. Is there a real need for a short-stay unit in Al Ain, United Arab Emirates? (Briefing) 237-239

David, A. S. see Senior, C. et al (Computers in psychiatry) 775-778

Davidson, Bob. Sinclair Stewart Sutherland (Obituary) 525

Davies, Pam see Ong, Yong-Lock (Psychiatry and the media) $720-722$

Davies, Teifion. Consent to treatment. Trust matters as much as information 200-201

Davison, Ken see Jackson, Sue et al (C) 59

Davison, Phil and Perez de Albeniz, Alberto. Reports prepared for Mental Health Review Tribunals and Managers Reviews (Audit) 364-366

Day, Kenneth and Jancar, Joze. Dr Blake Marsh and the Blake Marsh Lectures 26-29

De, Tamal see Shah, Ajit (C) 187

Dean, Anne (Head of Postgraduate Educational Services). Honorary Fellowships (Royal College) 590

Dean, Anne (Head of Postgraduate Educational Services) Joint meeting between the Royal College of Psychiatrist and the American Board of Psychiatry and Neurology (ABPN), 6 July 1996 (Royal College) 306

Denny, Roger see Rees, Harvey et al (C) 517-518

Denny, Roger et al. Providing a psychiatric service to liver transplant patients (C) 461

Dewsnap, Paul see Cooney, John et al (C) 57

Dhariwal, A. see Lengua, C. et al 535-537

Dick, Peter H. et al. Who's assessing needs-led assessment? (Audit) 290-293

Divall, P. and Jelley, M. Absolute power of discharge (C) 304

Dixey, Simon see Jolley, David et al (Audit) 503-505

Dixon, Mandy et al. Risk factors for acute psychiatric readmission $600-603$

Dorkins, Eluned. Training in prison psychiatry (Trainees forum) 52

Dorkins, Eluned and Brown, Christine. Section 37 Hospita Order and rights of appeal (C) 244

Dove, E. see Snaith, R. P. et al (Audit) 105-109

Dowson, J. H. et al. Characteristics of in-patients without psychosis. Implications for service provision and the recognition of personality disorder 553-556

Dowson, Jonathan H. et al. Supervision registers: operational problems (C) 122

Drummond, Lynne M. see Ging, John (C) 460

Drybala, Gary see Winston, Tony 557-560

Duffett, Richard (Research Unit) and Lelliott, Paul (Director Research Unit). Junior doctors' training in the theory and the practice of electroconvulsive therapy (Trainees' forum) 563-565
Duffey, P. et al. Tardive dyskinesia - how is it prevented and treated? (C) 724

Duncan, Denise see McConnell, Harry et al (Drug information quarterly) 642-645

Duncan, Denise see Taylor, David (Authors' reply) (C) 784

Duncan, Denise see Taylor, David (Drug information quarterly) 221-223

Duncan, Denise et al. Tardive dyskinesia - how is it prevented and treated? (Drug information quarterly) 422-425

Dunn, John. Dioclein - a new drug from an old plant. Letter from Brazil (Briefing) 235-236

Dunn, John. The rocky road - crack in Brazil. Letter from Brazil 373-374

Dunn, Mark et al. A repeat audit of the Cognitive Analytic Therapy Clinic at Guy's Hospital (Audit) 165-168

Durham, Tessa see Dick, Peter H. et al (Audit) 290-293

Dyer, James A. T. see Atkinson, Jacqueline M. et al 91-94

Eagles, John M. see Robertson, Carol 498-500

Eagles, John M. Assessment of suicide risk (C) 660

Eagles, John M. Should psychiatrists support CPA, guidelines and routine outcome measurements? (C) 377

Eastley, Rebecca and Nowers, Mike. A community mental health team for the elderly: a survey of GPs' views on the service 88-90

Eastman, Nigel. Hybrid justice: proposals for the mentally disordered in the Crime (Sentences) Bill. The ethical, legal and health service cost implications (Editorial) 129-131

Eastwood, Nigel and Pugh, Robert. Long-term medication in depot clinics and patients' rights: an issue for assertive outreach 273-275

Ebrahim, Irshaad see Shergill, Sukhwinder S. et al 760-763

Eccleston, Donald see Jackson, Sue et al (C) 59

Edelman, Katrin see Cooney, John et al (C) 57

Ellis, David and Lewis, Simon. Psychiatric presentations to an A\&E department 627-630

Ellis, Mary M. see Williams, D. D. R. et al 23-25

El-Rufaie, Omer E. F. see Daradkeh, Tewfik K. et al (Briefing) 237-239

Eminson, D. M. and Green, J. M. Role conflict and barriers to learning for senior registrars in child and adolescent psychiatry 339-342

Etchegoyen, Alicia and Stubley, Joanne. Nursery observation in the training of child psychiatry registrars 156-159

Evans, Jonathan see Denny, Roger et al (C) 461

Famuyiwa, O. O. Child abuse and neglect in sub-Saharan Africa 336-338

Famuyiwa, O. O. Objective structured clinical examination (C) $459-460$

Farooq, Saeed et al. An investigation of the adequacy of psychiatric interviews conducted through an interpreter 209-213

Fear, Christopher see Farooq, Saeed et al 209-213

Fearon, P. see Clarke, M. et al (Trainees' forum) 501-502

Feigenbaum, Janet D. Negative views of the mother after childhood sexual abuse (Women's mental health) 477-479

Fergusson, Grace see Robertson, Carol et al 699-702

Ferris, Rob. Psychiatry and the death penalty 746-748

Filson, Pam and Kendrick, Tony. Survey of roles of community psychiatric nurses and occupational therapists 70-73

Flynn, Tom see Robling, Siri-Ann et al (Audit) 440-444

Foster, S. E. see Miller, H. E. J. et al (Audit) 286-289

Freeman, Chris. Neurosurgery for mental disorder in the UK (Editorial) 67-69

Freeman, Chris P. L. see Robertson, Carol et al 699-702

Freeman, Hugh. Eleventh Annual TAPS Conference (Briefing) 233-234

Freeman, Hugh. Ismond Rosen (Obituary) 252-253 
Gallagher, Dominic see Henderson, Tom et al 136-138

Gaskell, Keith see Agarwal, Meena et al 205-208

Geddes, John. Using evidence about clinical effectiveness in everyday psychiatric practice 390-393

Gelder, Michael and Mayou, Richard. Oxford University Department of Psychiatry 1969 to 1996. 328-330

George, Mohan see Dixon, Mandy et al 600-603

George, Shoba see Smith, Simon et al (C) 303

Ghubash, Rafia see Daradkeh, Tewfik K. et al (Briefing) 237-239

Gilluley, Paul L. see James, David V. 764-768

Ging, John and Drummond, Lynne M. Psychotherapy experience for trainees (C) 460

Girling, D. M. see Green, S. et al 353-357

Goddard, Nick et al. Sharing medical records: comparison of general psychiatric patients with somatisation disorder patients 489-491

Goldberg, David (London Commissioner). London's mental health services (Editorial) 65-66

Goldberg, Ilfra. Flexible training in psychiatry (Editorial) 387-388

Golynkina, Katya see Dunn, Mark et al (Audit) 165-168

Grace, J. B. and Young, A. H. Doses of carbamazepine and valproate in bipolar affective disorder (C) 784

Graham, Philip. Child and Adolescent Services. Young People and Protective Legislation. Safeguards for Young Minds. R. Williams and R. White (eds) (Book review) 669-670

Gravestock, Shaun. You're on Trial. Sheila Hollins et al (Book review) 668

Gravestock, Shaun. You're under Arrest. Sheila Hollins et al (Book review) 668

Gravestock, Shaun and Bouras, Nick. Survey of services for adults with learning disabilities 197-199

Gray, Nicola see Salib, Emad et al (C) 459

Gray, Nicola and Salib, Emad. Asylum-seekers: self-referrals to a large psychiatric hospital 751-753

Green, J. M. see Eminson, D. M. 339-342

Green, S. et al. Service provision for elderly people with longterm functional illness 353-357

Green, Stephen see Baxter, Beelin et al (Audit) 360-363

Greenberg, Maurice see Shergill, Sukhwinder S. et al 760-763

Gregory, Carol see Robling, Siri-Ann et al (Audit) 440-444

Grounds, A. T. see Dowson, J. H. et al 553-556

Grounds, Adrian. Commentary on "Inquiries: who needs them?" (Editorial) 134-135

Gunn, John see McIvor, Ronan J. et al (Briefing) 176-178

Gurr, Myra and Hansen, Anne. NEWPIN: an opportunity for positive change (Women's mental health) 480-482

Haghighat, Rahman. Psychiatry in Lithuania: the highest rate of suicide in the world (Briefing) 716-719

Haldane, Douglas see Birtchnell, John (Obituary) 733-734

Haley, C. J. Evidence based medicine (C) 302-303

Hall, David J. see Carey, Stephen (C) 789

Hallam, Angela see Schneider, Justine 331-333

Halpern, Adina and Szmukler, George. Psychiatric advance directives: reconciling autonomy and non-consensual treatment (Editorial) 323-327

Hambridge, D. M. Request for information (C) 245

Hampson, Michele see Cutajar, Peter 640-641

Handy, S. see Lengua, C. et al 535-537

Hansen, Anne see Gurr, Myra (Women's mental health) 480-482

Harcourt Williams, Margaret (Archivist). The College archives. Minutes yesterday and today (Royal College) 589

Hardwick, Fawzea see Williams, D. D. R. et al 23-25

Harling, Kit. Doctors and occupational health services (C) 241-242

Harper Gilmour, W. see Atkinson, Jacqueline M. et al 91-94

Harris, Victor. Skit (Personal view) 512-513

Harvey, R. H. see Marriott, S. V. L. (Research Unit) et al 618-621

Hassanyeh, Fuad see Tough, Sandra L. et al 492-494
Hatfield, Barbara et al. Psychiatric emergencies: assessing parents of dependent children 19-22

Hawthorne, M. see Duffey, P. et al (C) 724

Heaton-Ward, W. Alan. Brian Herbert Kirman (Obituary) 383-384

Henderson, Tom et al. A survey of the use of the electrocardiogram in psychiatry 136-138

Herriot, Peter M. and Bhui, Kamaldeep. Educational supervision sessions between consultants and trainees (C) $785-786$

Herzberg, Joe see Spear, Jon et al 401-404

Higgon, John see Rothwell, Neil et al 636-639

Hill, M. A. Alwyn Byron Griffiths (Obituary) 312

Hillam, Jonathan et al. Administration of ECT by trainee psychiatrists. An audit of supervision, adequacy of tuition and attitudes (Audit) 217-220

Hillman, Jonathan see Cooney, John et al (C) 57

Hilton, Claire. Job-sharing (C) 243-244

Hilton, Trudi see Taylor, David et al 680-683

Hird, M. see Snaith, R. P. et al (Audit) 105-109

Hobbs, Mike. False memories of child sexual abuse (Video review) 119

Hodgkinson, Peter. Invited commentary on: Psychiatry and the death penalty $749-750$

Hodgson, Richard see Boardman, Jed et al 202-204

Hodgson, Richard. Case report (C) 123-124

Holland, J. A. see Duffey, P. et al (C) 724

Holloway, Frank. 24-hour nursed care for people with severe and enduring mental illness (Editorial) 195-196

Holloway, Frank (Series Editor). Psychiatry: a risky business? (Risk assessment) 36

Holloway, Frank. The assessment and management of risk in psychiatry: can we do better? (Author's reply) (C) 583

Holloway, Frank. The assessment and management of risk in psychiatry: can we do better? (Risk assessment) 283-285

Holmes, Jeremy. Unexpected deaths in psychiatry (C) 187-188

Holmes, Robert see Taylor, David et al 680-683

Howard, Christopher (Chairman, Special Interest Group in Philosophy). International conference on philosophy and mental health (Briefing) 179-180

Howlett, Michael. Inquiries: who needs them? (C) 583-584

Hughes, J. C. and Cook, C. C. H. Disulfiram implantation (C) 186

Hughes, Julian C. Community psychiatry in the RAF: an evaluative review 418-421

Hughes, Patricia. The role of the speciality tutor in the training of junior doctors in psychiatry (Trainees' forum) 435-437

Humphreys, Martin S. Non-consultant psychiatrists knowledge of emergency detention procedures in Scotland. A national survey 631-635

Hunt, Neil see Robling, Siri-Ann et al (Audit) 440-444

Hutcheson, Fiona see Atkinson, Jacqueline M. et al 91-94

Huyse, Frits J. and Smith, Graeme C. Consultation-liaison: from dream to reality. A systematic approach to developing C-L mental health service delivery (Editorial) 529-531

Ikkos, George see Ashaye, Olakunle et al 145-147

Iparragirre, Boni and Salib, Emad. Non-conversion of Section 5(2) (C) 121

Jackson, Sue et al. Suicide in the severely mentally ill (C) 59 Jacobson, Robin see Aitken, Peter 550-552

James, Anthony. James Barr McWhinnie (Obituary) 799-800

James, David V. and Gilluley, Paul L. Psychotic patients and patent applications. The mad scientist revisited? 764-768

Jancar, Joze see Day, Kenneth 26-29

Jelley, M. see Divall, P. (C) 304

Jenkins, Rosie see Jolley, David et al (Audit) 503-505 
Johnson, D. A. W. Options for Improving Patient Care in Schizophrenia. Hugh Freeman (ed.) (Book review) 669

Johnson, D. A. W. and Rasmussen, J. G. C. Professional attitudes in the UK towards neuroleptic maintenance therapy in schizophrenia. The problem of inadequate prophylaxis 394-397

Johnson, Hazel see Pinner, Gillian et al (C) 376

Jolley, David et al. First light: old age psychiatry in Wolverhampton 1995 to 1996 (Audit) 503-505

Jones, Ian R. see Sullivan, Gary (Education) 449-450

Kaanders, Hetty see Spear, Jon et al 401-404

Kaplan, Carole and Ralph, Paul. Mental Health Review Tribunals: time for reform? (Editorial) 257

Kapur, Navneet see Ramchandani, Paul et al (Trainees 'forum 711-713

Kathriarachchi, S. T. see Cawthra, R. et al (Trainees' forum) 50-51

Katsabouris, G. see Thomas, A. et al 692-694

Kay, Rob et al. Using the media during Mental Health Week (Psychiatry and the media) 451-453

Kellett, John. The dispensable psychiatrist (Personal view) $581-582$

Kelly, Doreen see Kay, Rob et al (Psychiatry and the media) $45 i-453$

Kelly, Frank see Cooney, John et al (C) 57

Kelly, S. J. The Bexley Hospital population nine years on 542-544

Kemp, Roisin and Loftus, Josephine. Beckett: portraits of the artist in exile (Psychiatry and the media) 656-658

Kendell, R. E. (President). Financial implications of Calman changes in psychiatry (C) 785

Kendell, R. E. (President) and Pearce, Alison (Research Unit) Consultant psychiatrists who retired prematurely in 1995 and 1996. 74I-745

Kendell, Robert (President). The College and 'clinical effectiveness' (Editorial) 385-386

Kendrick, Tony see Filson, Pam 70-73

Kendrick, Tony. Needs Assessment in General Practice. S J. Gillam and S. A. Murray (eds) (Book review) 671

Kennedy, Michael see Turner, Mark (Editorial) 465-466

Kennedy, Peter. From problems to solutions (Editorial) 593-594

Kennerley, Helen. Step by step: helping yourself to cope with panic (Video review) 118-119

Kerr, Alan. Thomas Szasz. In conversation (Interview) 39-44

Khin-Maung-Zaw. Psychiatric services in Myanmar. A historical perspective (History of psychiatry) 506-509

Khoosal, Deenesh see Mactier, Fiona 4-5

Kidd, Brian see Powell, Richard A. (C) 187

King, J. R. The sweet smell of successful psychiatry (Outside working hours) 456-458

King, Michael see Leavey, Gerard et al (Editorial) 739-740

King, Michael see Warner, James P. (Editorial) 532-534

Kingdon, David. The Care Programme Approach: comment on 'Time for frank talking' $430-431$

Klasen, Henrikje et al. Women, mental health and the family (Editorial) $467-468$

Knapp, Martin. The first twelve months of a community support bed unit (C) $57-58$

Knowles, Jane. The conversion of Holloway Sanatorium (Briefing) 232

Knowles, Jane. 'The Reading model': an integrated psychotherapy service 84-87

Kohen, D. see Crawford, M. J. 625-626

Kuipers, Elizabeth see Scazufca, Marcia (Women's mental health) 469-47

Lally, Sukh see Lynch, Sean (C) 517

Lancefield, M. N. see Malcolm, M. T. et al (C) 461

Lang, Fiona H. see Mitchell, John R. et al 6-9
Langley, Gordon. Meeting Gerald Caplan (Briefing) 181-183

Laugharne, Richard see Stafford, Anna 757-759

Launer, M. A. Edward Townley Downham (Obituary) 191

Lavin, Noel I. Ralph Emery (Obituary) 799

Leavey, Gerard et al. Health research on the Irish in Britain: invisible and excluded (Editorial) 739-740

Leibowitz, Judy see Burns, Tom 426-429

Lelliott, Paul (Director, Research Unit) see Duffett, Richard (Research Unit) (Trainees' forum) 563-565

Lelliott, Paul (Director, Research Unit). Should psychiatrists support CPA, guidelines and routine outcome measurement? (Editorial) 1-2

Lengua, C. et al. Survey of young offenders in a regional secure unit 535-537

Lewis, Martyn see Boardman, Jed et al 202-204

Lewis, Simon see Ellis, David 627-630

Littlewood, Roland see Leavey, Gerard et al (Editorial) 739-740

Loader, Peter see Stormont, Fiona et al 495-497

Lockwood, Kate. Future directions of psychotherapy in the NHS: adaptation or extinction? (Briefing) 180

Lodge, George J. Assessing risk of violent behaviour 703-706

Loftus, Josephine see Kemp, Roisin (Psychiatry and the media) 656-658

Logan, Katharine see Shajahan, Polash et al 695-698

Longhurst, James G. and Weiss, Erica L. Tardive dyskinesia how is it prevented and treated? (C) 723-724

Lough, S. see Green, S. et al 353-357

Lovett, J. W. T. Politics of psychiatry (C) 377

Lucas, Benjamin. Members of a community mental health team 547-549

Lusman, Diane see Blower, Aileen 151-153

Lynch, Sean and Lally, Sukh. Psychiatric liaison services to the Scottish Liver Transplant Unit (C) 517

McAllister-Williams, R. H. The description of primary delusions: confusion in standard texts and among clinicians 346-349

McArdle, Paul see Agarwal, Meena et al 205-208

Macaskill, Ann et al. The Defeat Depression Campaign. A mid-point evaluation of its impact on general practitioners 148-150

Macaskill, Norman see Macaskill, Ann et al 148-150

McAskill, Robyn and Taylor, David. Psychotropics and hyponatraemia (Drug information quarterly) 33-35

McBreen, Marie see Robling, Siri-Ann et al (Audit) 440-444

McBride, Andrew J. see Ali, Imad M. 343-345

McBride, Andrew J. see Summers, Zelda et al (C) 244-245

McCartney, Mark. Second medical recommendations and good practice (C) 58

McClintock, Tom. Official crime statistics - no reassurance for the victims of crime (Editorial) 258-259

McConnell, Harry see Duncan, Denise et al (Drug information quarterly) 422-425

McConnell, Harry et al. Choice of neuroleptics in epilepsy (Drug information quarterly) 642-645

Mclvor, Ronan J. et al. Psychological care of staff following traumatic incidents at work (Briefing) 176-178

McLaren, P. M. see Okhai, M. F. (Trainees' forum) 227-228, (Authors' reply) (C) 515

McManus, Pauline see Rothwell, Neil et al 636-639

Mactier, Fiona and Khoosal, Deenesh. Essential information for filling consultant posts 4-5

Maharajh, Hari. Cocaine and social transformation in Trinidad and Tobago. Letter from Trinidad (Briefing) 184-185

Mahmood, Rafeek et al. Visit to Abbasiah Hospital, Egypt (Briefing) 45-46

Malcolm, M. T. Disulfiram implantation (C) 375-376

Malcolm, M. T. Section 4 or $5(2)$ (C) 58

Malcolm, M. T. et al. Section 3 - hidden consequences (C) 461 
Mallett, Paul and Powell, Robin. London bed fever (C) 584 Mann, S. A. Examiners and assessors (Royal College) 189 Mannion, Laura see Sloan, Darina et al (Education) 646-648 Mannion, Laura et al. Rapid tranquillisation: are we getting it right? $411-413$

Marchevsky, David. Evidence-based medicine (C) 460-461

Marlowe, J. see Snaith, R. P. et al (Audit) 105-109

Marriott, S. V. L. (Research Unit) et al. Health in hostels: a survey of hostel dwelling women 618-621

Marriott, Sarah (Research Unit). Clinical effectiveness - a series of perspectives 389

Marshall, Philip D. Incapacity Benefit (C) 242

Martin, Barbara see Kay, Rob et al (Psychiatry and the media) 451-453

Martin, Clare see Mitchell, Alexander J. et al (Briefing) 578-580

Masterton, George see Mitchell, John R. et al 6-9

Masterton, George see Shajahan, Polash et al 695-698

Mayou, Richard see Gelder, Michael 328-330

Meagher, David see Byrne, Peter (Trainees' forum) 707-710 Meagher, David see Quinn, John (Education) 367-368

Meats, Philip and Ashton, Terry. Nurses' help in psychiatric out-patient clinics 677-679

Melvin, Diane and Sherr, Lorraine. Women and children living with HIV infection. Some psychological concerns (Women's mental health) 472-476

Miller, H. E. J. et al. Psychotropic medication in learning disabilities: audit as an alternative to legislation (Audit) 286-289

Mindham, R. H. S. (Chief Examiner). Forthcoming changes to the MRCPsych Part II Examination (Royal College) 248

Mitchell, Alexander $J$. et al. Bibliographic databases in psychiatry: an overview (Briefing) 578-580

Mitchell, John R. et al. Providing a psychiatric service to liver transplant patients. The first two years of the Scottish Liver Transplant Unit 6-9

Mohamad, Hadi see Hatfield, Barbara et al 19-22

Moliver, Adam. CPD and the Fellowship (C) 242

Morgan, H. G. Management of suicide risk (Risk assessment) 214-216

Morgan, Jessica see Blakey, Andrew et al 622-624

Morgan, John Farnill. The role of research in psychiatric training: the trainees' perspective (C) 787

Morrison, A. The assessment and management of risk in psychiatry: can we do better? (C) 583

Moulton, June see Spear, Jon et al 401-404

Muijen, Matt. Inquiries: who needs them? (Editorial) 132-133

Muir, Jacqueline see Sillifant, Kate et al 612-614

Murthy, R. see Newton, K. L. et al 408-410

Mutiboko, Isaac Kunguru. Tamirisa Venkateswarlu (Obituary) 667

Nabi, D. W. see Al-Adwani, Andrew (C) 725

Nabi, Waheed see Al-Adwani, Andrew (C) 303

Naik, Prakash see Ardagh-Walter, Nick et al 139-14

Nangle, Marie see Quinn, John et al 597-599

Nasr, Ashraf et al. Child and adolescent self-poisoning: service-related characteristics 267-269

Nathan, Rajan. Assessment of suicide risk (C) 660

Newton, K. L. et al. Antipsychotic prescribing in light of the consensus statement of the College 408-410

Ng, A. M. N. see Green, S. et al 353-357

Nicholls, K. R.. Holding powers in A\&E departments. A cause for concern 615-617

Nicol, A. see Macaskill, Ann et al 148-150

Nightingale, Anne et al. Counselling and support services for civil emergencies and major incidents. Psychodynamic reflections $486-488$

Noble, Fiona S. Long-term psychiatric care in Papua New Guinea (Briefing) 113-116

Nokes, E. M. (Librarian). Library stock (Royal College) 125

Nowers, Mike see Eastley, Rebecca 88-90
O'Boyle, James see Sloan, Darina et al (Education) 646-648 O'Brien, Maureen and Sullivan, Gary. Two management courses for senior/specialist registrars (Education) 229-231

Odell, Sue see Commander, Martin et al 260-263

Oedipus and Witzelsucht. Christmas crossword 783

Okhai, M. F. and McLaren, P. M. Re-evaluation of the role of trainee psychiatrists in secluding general adult psychiatric patients (Trainees' forum) 227-228

Okhai, M. F. and McLaren, P. M. The doctor and seclusion (Authors reply) (C) 515

Olajide, Dele and Cox, John (Dean). Mental health services for people from black and other ethnic minorities (Royal College) 305

Ong, Yong-Lock and Davies, Pam. Conflicts of a 90-year-old transsexual. To be, or not to be? (Psychiatry and the media) 720-722

Ovuga, Emilio see Boardman, Jed (Briefing) 649-655

Owens, Julie see Brittlebank, Andrew (Education) 169-170

Oyebode, Femi see Dixon, Mandy et al 600-603

Oyebode, Femi see Farooq. Saeed et al 209-213

Patel, Vikram. Mental illness in Goa, India (Briefing) 299-301

Paton, Carol see Beer, M. Dominic et al 142-144, (Authors reply) (C) 516

Paton, Carol see Taylor, David et al 680-683

Patterson, Diana see Sharkey, John J. 16-18

Patterson, Lesley see Atkinson, Jacqueline M. et al 91-94

Paul, Moli see Smith, Simon et al (C) 303

Pearce, Alison (Research Unit) see Kendell, R. E. (President) 741-745

Pemberton, S. see Snaith, R. P. et al (Audit) 105-109

Pereira, Stephen see Beer, M. Dominic et al 142-144, (Authors' reply) (C) 516

Pereira Gray, Denis. Fellowships of Royal Colleges (C) 120-121

Perez de Albeniz, Alberto see Davison, Phil (Audit) 364-366

Peutz, Margreet. Teaching cultural aspects of psychiatry 160-161

Phillips, Jeanette. Meeting the psychiatric needs of children in foster care. Social workers' views 609-61

Phillips, M. L. see Senior, C. et al (Computers in psychiatry) 775-778

Philo, G. Changing media representations of mental health (Psychiatry and the media) 171-172

Piachaud, Jack see Cohn, Nancy (Briefing) 714-715

Pinner, Gillian et al. SSRI prescribing in the elderly: caution required $(C) 376$

Pinney, Alison see Yorston, Graeme (Audit) 566-569

Poole, Rob. Don't give up your day job (Outside working hours) 454-455

Porter, R. see Cawthra, R. et al (Trainees ' forum) 50-51

Pourgourides, Christina. A second exile: the mental health implications of detention of asylum seekers in the UK (Editorial) 673-674

Powell, Richard A. and Kidd, Brian. Increasing staff safety (C) 187

Powell, Robin see Mallett, Paul (C) 584

Preston, Ian see Mitchell, Alexander J. et al (Briefing) 578-580

Price, D. J. see Snaith, R. P. et al (Audit) 105-109

Prins, Herschel. The Mental Health Review Tribunal and the restricted patient (Risk assessment) 102-104

Pugh, Robert see Eastwood, Nigel 273-275

Quinn, John et al. Analysis of psychotropic drug advertising 597-599

Quinn, John and Meagher, David. Psychiatric trainees' research experiences and activities in the Eastern region of Ireland (Education) 367-368

Qureshi, J. see Newton, K. L. et al $408-410$ 
Raistrick, Duncan. Task force to review services for drug misusers (Editorial) 595-596

Ralph, Paul see Kaplan, Carole (Editorial) 257

Ramchandani, Paul $e t$ al. Methods of registrar post allocation (Trainees' forum) 711-713

Rao, Rahul. The role of carers in the information process in dementia 264-266

Rasmussen, J. G. C. see Johnson, D. A. W. 394-397

Rawson, S. see Snaith, R. P. et al (Audit) 105-109

Read, S. see Brooker, C. (Editorial) 675-676

Read, Stephen see Sillifant, Kate et al 612-614

Rees, Harvey et al. The rush for the MRCPsych? (C) 517-518

Reid, David see Dick, Peter H. et al (Audit) 290-293

Reid, G. E. Community psychiatry in the RAF: an evaluative review (C) 786-787

Riccio, Massimo see Atkins, Maria et al (Drug information quarterly) 224-226

Richards, Josephine see Chaplin, Robert (Psychiatry in art) 276-277

Rigby, Elizabeth see Ashaye, Olakunle et al 145-147

Robertson, Carol et al. ECT in Scotland 699-702

Robertson, Carol and Eagles, John M. Review of ECT prescription and outcome in depression 498-500

Robertson, Emma see Dixon, Mandy et al 600-603

Robertson, John see Mahmood, Rafeek et al (Briefing) 45-46

Robinson, Brian see Rees, Harvey et al (C) 517-518

Robling, Siri-Ann et al. An audit of drug management of acute behavioural disturbance (Audit) 440-444

Roldan, Feli see Smith, Simon et al (C) 303

Rollin, Henry R. David Monas Leiberman (Obituary) 63

Rollin, Henry R. Humble pie (Vignette) 316-317

Rollin, Henry R. In my Father's house are many mansions (Vignette) 514

Rothwell, Neil et al. Evaluation of moving an acute psychiatric ward from a psychiatric hospital to a general hospital setting 636-639

Roy, David. Clinical risk management: an emerging agenda for psychiatry (Risk assessment) 162-164

Rutherford, Joan see Ul-Hassan, Zaffar (C) 787-788

Ryle, Anthony see Dunn, Mark et al (Audit) 165-168

Ryman, Ann. Lithium monitoring in hospital and general practice (Audit) 570-572

Salib, Emad see Gray, Nicola 751-753

Salib, Emad see Iparragirre, Boni (C) 121

Salib, Emad $e t$ al. Friday the 13th and fatal self-harm (C) 459

Salmon, Gill and Connor, Anne Marie. Psychological support for a community paediatric nursing team 350-352

Salter, Mark. Chlormethiazole or chlordiazepoxide? (C) 186

Sandford, John. Postgraduate training in psychiatry (C) 120

Sashidharan, Sashi see Commander, Martin et al 260-263

Sayal, Kapil see Ramchandani, Paul et al (Trainees' forum) $711-713$

Sayal, Kapil and Taylor, Eric. Drug treatment in attention deficit disorder: a survey of professional consensus $398-400$

Scazufca, Marcia and Kuipers, Elizabeth. Impact on women who care for those with schizophrenia (Women's mental health) 469-471

Schneider, Justine and Hallam, Angela. Specialist work schemes: user satisfaction and costs 331-333

Scott, Allan I. F. Unexpected therapeutic benefit of Community Care Order application (C) 124

Scott, David see Nightingale, Anne et al 486-488

Senior, C. et al. Psychiatry and the WWW: some implications (Computers in psychiatry) 775-778

Shah, Ajit and De, Tamal. Fundholding and fragmentation of care (C) 187

Shajahan, Polash et al. Characteristics of patients admitted to in-patient psychiatric care following parasuicide 695-698
Sharkey, John J. and Patterson, Diana. Intake of and attitudes to alcohol and alcoholism. A questionnaire survey among future doctors 16-18

Sheldon, Laurence (CTC) see Cornwall, Peter (CTC) (Briefing) 117

Shergill, Sukhwinder S. et al. Predictors of length of stay in day hospital patients 760-763

Sherr, Lorraine see Melvin, Diane (Women's mental health) $472-476$

Sillifant, Kate et al. Monitoring of patients on high dose antipsychotic medication 612-614

Simpkins, Audrey see Dick, Peter H. et al (Audit) 290-293

Simpson, N. see Miller, H. E. J. et al (Audit) 286-289

Simpson, Neill. Meeting the mental health needs of adults with mild learning disabilities (Royal College) 247

Singh, Swaran P. and Beck, Andrew J. 'No sex please, we're British'. Taking a sexual history from in-patients 99-101

Sloan, Darina see Mannion, Laura et al 411-413

Sloan, Darina et al. Participating in the MRCPsych examinations: the patients' experience (Education) 646-648

Smith, Alan. Survey of locked facilities in Scottish psychiatric hospitals 77-79

Smith, George see Nightingale, Anne et al 486-488

Smith, Graeme C. see Huyse, Frits J. (Editorial) 529-531

Smith, Sarah see Swinton, Mark 538-541

Smith, Simon et al. Non-attendance at clinics (C) 303

Smyth, M. G. A glossary of television-related symptoms in psychosis 545-546

Snaith, R. P. Highly specialised services (C) 59

Snaith, R. P. et al. Psychosurgery: description and outcome study of a regional service (Audit) 105-109

Soppitt, Richard see Smith, Simon et al (C) 303

Spear, Jon et al. A volunteer project for elderly people with mental health problems $401-404$

Spence, Sean. Razor head. The performance art of Marina Abramovic (Psychiatry and the media) 53-55

Spence, Sean A. National survey of psychiatric intensive care units (C) 515-516

Spencer, Douglas A. Mental handicap resettlement readmissions (C) 60

Spencer, Seymour. Reparanoitee (Vignette) 378

Spencer, Seymour. The smile in endogenous depression (Vignette) 659

Spye, Mark see Salib, Emad et al (C) 459

Stafford, Anna and Laugharne, Richard. Evaluation of a client held record introduced by a community mental health team 757-759

Stark, Cameron see Craig, Neil 684-686, 687-691

Stark, Cameron see Henderson, Tom et al 136-138

Stark, Cameron see Kay, Rob et al (Psychiatry and the media) $451-453$

Stein, Dan J. Psychiatry on the Internet: survey of an OCD mailing list 95-98

Stein, George. Meetings with doctors in the staff grades: the development of affiliate status 405-407

Storer, David (Chairman, Manpower Committee). Recruiting consultants (Editorial) 3

Storer, David. Things have to get better (Editorial) 737-738

Stormont, Fiona et al. Concerns about the children of psychiatric in-patients - what the parents say 495-497

Stubley, Joanne see Etchegoyen, Alicia 156-159

Sullivan, Gary see O'Brien, Maureen (Education) 229-231

Sullivan, Gary. The Collegiate Trainees' Committee (Trainees' forum) 358-359

Sullivan, Gary (Former Chairman, CTC) et al. The Collegiate Trainees' Committee position on the use of logbooks in training (Trainees' forum) 278-279

Sullivan, Gary and Jones, Ian R. Membership course or masters course? (Education) 449-450

Summers, Zelda et al. Diazepam and detoxification (C) 244-245

Sussams, P. see Dowson, J. H. et al 553-556 
Sussams, Pamela see Dowson, Jonathan H. et al (C) 122

Swanwick, Gregory see Sloan, Darina et al (Education) 646-648

Swinton, Mark and Smith, Sarah. Costs of physical health care for self-injuring patients 538-541

Szmukler, George see Halpern, Adina (Editorial) 323-327

Tait, David. Bill Boyd. In conversation (Interview) 769-774

Taylor, David see Duncan, Denise et al (Drug information quarterly) 422-425

Taylor, David see McAskill, Robyn (Drug information quarterly) 33-35

Taylor, David see McConnell, Harry et al (Drug information quarterly) 642-645

Taylor, David et al. Evaluating and improving the quality of risperidone prescribing 680-683

Taylor, David and Duncan, Denise. Doses of carbamazepine and valproate in bipolar affective disorder (Authors' reply) (C) 784

Taylor, David and Duncan, Denise. Doses of carbamazepine and valproate in bipolar affective disorder (Drug information quarterly) 221-223

Taylor, Eric see Sayal, Kapil 398-400

Taylor, John R. and Cookson, Ian B. An audit of out-patients on 'higher dose' antipsychotics (Audit) 445-448

Taylor, John R. and Wilkinson, Greg. HoNOS v. GP opinion in a shifted out-patient clinic $483-485$

Thacker, Simon. Clinical involvement by medical secretaries and receptionists: a questionnaire survey (C) 122

Thacker, Simon. Trainees in the specialities (C) 375

Thomas, A. et al. Staff perception on reduction of medication in patients with chronic schizophrenia 692-694

Thomas, Huw see Cooney, John et al (C) 57

Thompsell, Amanda see Hillam, Jonathan et al (Audit) 217-220

Thompson, C. (Registrar). Approval of doctors under Section 12 of the Mental Health Act (1983) (Royal College) 247

Thompson, C. (Registrar). Psychiatrists' professional opinions to the media (Royal College) 62

Thompson, C. (Registrar). The culture of enquiry (C) 241

Thompson, Chris (Registrar) see Mahmood, Rafeek et al (Briefing) 45-46

Tidmarsh, David. Norman Boyce Le Couteur (Obituary) 253-254

Timms, Philip. Loose talk: psychiatrists, the media and ethics (Psychiatry and the media) 573-575

Tobiansky, Robert see Hillam, Jonathan et al (Audit) 217-220

Tombs, David see Ardagh-Walter, Nick et al 139-141

Tough, Sandra L. et al. The Newcastle Clozapine Clinic 492-494

Treasure, Janet. Talking about Anorexia. Maroushka Munro (Book review) 671

Trezise, Kate and Conlon, Bill. Effects of changes in practice of electroconvulsive therapy over a two year period 10-12

Trigwell, P. see Snaith, R. P. et al (Audit) 105-109

Turnbull, Gill and Chalder, Trudie. Effects of education on attitudes to deliberate self-harm 334-335

Turner, Mark and Kennedy, Michael. Tarasoff and the duty to warn third parties (Editorial) $465-466$

Ul-Hassan, Zaffar and Rutherford, Joan. Stalking the stalkers (C) 787-788

van Os, Jim. Psychiatric training in the Netherlands (C) 58 Vereker, Margaret see Cole, Mary 414-417
Vincenti, G. E. P. Phlebotomists - not always a good thing (C) 661

Vostanis, Panos see Nasr, Ashraf et al 267-269

Wallace, John. Psychiatry in Vietnam: a personal impression 779-780

Walsh, E. see Clarke, M. et al (Trainees' forum) 501-502

Warner, James see Cooney, John et al (C) 57

Warner, James P. and King, Michael. Evidence-based medicine and the journal club: a cross-sectional survey of participants' views (Editorial) 532-534

Warren, Estelle H. Alfred James Warren (Obituary) 525-526

Warriner, C. H. see Malcolm, M. T. et al (C) 461

Watson, J. P. see Dunn, Mark et al (Audit) 165-168

Watson, P. E. CPA: should it carry a government health warning? (C) 723

Watson, P. E. CPA: should it carry a government health warning? A personal experience $432-434$

Wattis, J. P. (Chairman, Section for Psychiatry of Old Age) Trainees in the specialities (C) 375

Webb, Marcus (Chairman. Irish Division). Republic of Ireland: White Paper on a new Mental Health Act. Response of the Irish Division of the Royal College of Psychiatrists (Royal College) 307-311

Webster, Jeni see Hatfield, Barbara et al 19-22

Weir, K. Predicting attendance at child and adolescent psychiatry clinics (C) 243

Weiss, Erica L. see Longhurst, James G. (C) 723-724

Welch, Sarah see Klasen, Henrikje et al (Editorial) 467-468

Wessely, Simon see Goddard, Nick et al 489-491

Wheeler, Jason. CPA: Should it carry a government health warning? (C) 723

Whitcher, S. K. see Green, S. et al 353-357

White, Sue see Tough, Sandra L. et al 492-494

Whitehead, Tony. Forgetfulness and blame (C) 725-726

Wilcock, Austin see Tough, Sandra L. et al 492-494

Wilkie, Alcuin. Australia - being there (in praise of general practice) (Briefing) 48-49

Wilkinson, Greg see Taylor, John R. 483-485

Williams, Cindy see Stormont, Fiona et al 495-497

Williams, D. D. R. et al. Intensive home nursing. An innovation in old age psychiatry 23-25

Williams, David see Summers, Zelda et al (C) 244-245

Williams, Hugh. Chlormethiazole or chlordiazepoxide? (C) 187

Williams, Olwen see Baxter, Beelin et al (Audit) 360-363

Williams, Olwen see Dowson, Jonathan H. et al (C) 122

Winkley, Linda see Nasr, Ashraf et al 267-269

Winston, Tony and Drybala, Gary. Improving resuscitation skills in psychiatric hospitals. A multidimensional problem $557-560$

Witzelsucht see Oedipus 783

Wolfson, Paul see Barlow, Fiona 270-272

Wright, J. F. see Snaith, R. P. et al (Audit) 105-109

Yeung, Wai-song. Substance misuse in secondary students in Hong Kong 561-562

Yorston, Graeme. Independence of Mental Health Act medical recommendations (C) 788

Yorston, Graeme and Pinney, Alison. Use of high dose antipsychotic medication (Audit) 566-569

Young, A. H. see Grace, J. B. (C) 784

Younis, Yahia see Daradkeh, Tewfik K. et al (Briefing) 237-239

Yousaf, Farida see Cooney, John et al (C) 57

A supplement to the Psychiatric Bulletin

Printed in Great Britain by Henry Ling Ltd, at the Dorset Press, Dorchester, Dorset 